\title{
\#USGS
}

National Water-Quality Assessment Program

\section{Water-Quality Assessment of the High Plains Aquifer, 1999-2004}

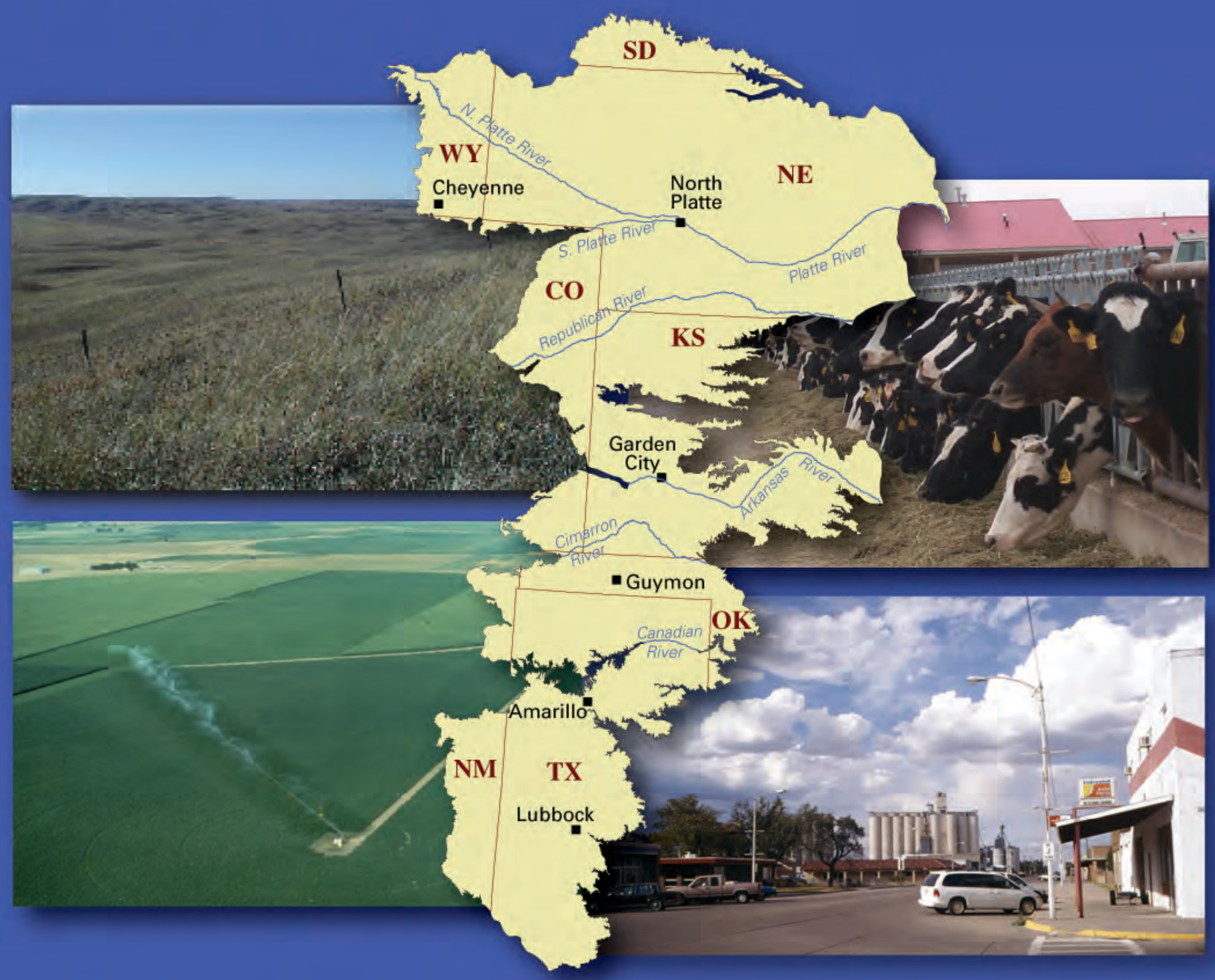

Professional Paper 1749

U.S. Department of the Interior

U.S. Geological Survey 


\section{Front Cover:}

Natural grasslands in the Nebraska Sand Hills, northern High Plains.

Photograph by

B.W. Bruce, U.S. Geological Survey

(U.S. Geological Survey)

Aerial view of an irrigated agricultural field, central High Plains.

Photograph by

R.R. Luckey, U.S. Geological Survey

(U.S. Geological Survey)
Cattle feeding operation, southern High Plains.

Photograph by

L. Fahlquist

(U.S. Geological Survey)

Sublette, Kansas

Photograph courtesy John Charlton

(Kansas Geological Survey) 


\section{Water-Quality Assessment of the High Plains Aquifer, 1999-2004}

By Peter B. McMahon, Kevin F. Dennehy, Breton W. Bruce, Jason J. Gurdak, and Sharon L. Qi

National Water-Quality Assessment Program

Volume comprises Chapters 1, 2, 3, 4

Professional Paper 1749 


\section{U.S. Department of the Interior DIRK KEMPTHORNE, Secretary}

\section{U.S. Geological Survey \\ Mark D. Myers, Director}

\section{U.S. Geological Survey, Reston, Virginia: 2007}

For product and ordering information:

World Wide Web: http://www.usgs.gov/pubprod

Telephone: 1-888-ASK-USGS

For more information on the USGS--the Federal source for science about the Earth, its natural and living resources, natural hazards, and the environment:

World Wide Web: http://www.usgs.gov

Telephone: 1-888-ASK-USGS

Any use of trade, product, or firm names is for descriptive purposes only and does not imply endorsement by the U.S. Government.

Although this report is in the public domain, permission must be secured from the individual copyright owners to reproduce any copyrighted materials contained within this report.

Suggested citation:

McMahon, Peter B., Dennehy, Kevin F., Bruce, Breton W., Gurdak, Jason J., and Qi, Sharon L., 2007, Water-quality assessment of the High Plains Aquifer, 1999-2004: U.S. Geological Survey Professional Paper 1749, 136 p. 


\section{FOREWORD}

The U.S. Geological Survey (USGS) is committed to providing the Nation with accurate and timely scientific information that helps enhance and protect the overall quality of life and that facilitates effective management of water, biological, energy, and mineral resources ( $h t t p: / /$ www.usgs.gov/). Information on the quality of the Nation's water resources is critical to assuring the long-term availability of water that is safe for drinking and recreation and suitable for industry, irrigation, and habitat for fish and wildlife. Population growth and increasing demands for multiple water uses make water availability, now measured in terms of quantity and quality, even more essential to the long-term sustainability of our communities and ecosystems.

The USGS implemented the National Water-Quality Assessment (NAWQA) Program in 1991 to support national, regional, and local information needs and decisions related to water-quality management and policy (http://water.usgs.gov/nawqa). Shaped by and coordinated with ongoing efforts of other Federal, State, and local agencies, the NAWQA Program is designed to answer: What is the condition of our Nation's streams and ground water? How are the conditions changing over time? How do natural features and human activities affect the quality of streams and ground water, and where are those effects most pronounced? By combining information on water chemistry, physical characteristics, stream habitat, and aquatic life, the NAWQA Program aims to provide science-based insights for current and emerging water issues and priorities.

From 1991 to 2001, the NAWQA Program completed interdisciplinary assessments in 51 of the Nation's major river basins and aquifer systems, referred to as Study Units (http://water. usgs.gov/nawqa/studyu.html). Baseline conditions were established for comparison to future assessments, and long-term monitoring was initiated in many of the basins. During the next decade, 42 of the 51 Study Units will be reassessed so that 10 years of comparable monitoring data will be available to determine trends at many of the Nation's streams and aquifers. The next 10 years of study also will fill in critical gaps in characterizing water-quality conditions, enhance understanding of factors that affect water quality, and establish links between sources of contaminants, the transport of those contaminants through the hydrologic system, and the potential effects of contaminants on humans and aquatic ecosystems.

The USGS aims to disseminate credible, timely, and relevant science information to inform practical and effective water-resource management and strategies that protect and restore water quality. We hope this NAWQA publication will provide you with insights and information to meet your needs and will foster increased citizen awareness and involvement in the protection and restoration of our Nation's waters.

The USGS recognizes that a national assessment by a single program cannot address all waterresource issues of interest. External coordination at all levels is critical for a fully integrated understanding of watersheds and for cost-effective management, regulation, and conservation of our Nation's water resources. The NAWQA Program, therefore, depends on advice and information from other agencies_-Federal, State, interstate, Tribal, and local—as well as nongovernmental organizations, industry, academia, and other stakeholder groups. Your assistance and suggestions are greatly appreciated.

Robert M. Hirsch

Associate Director for Water 


\section{Volume Contents}

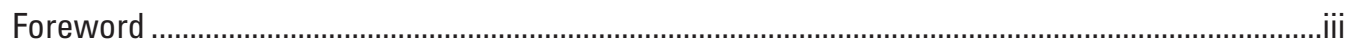

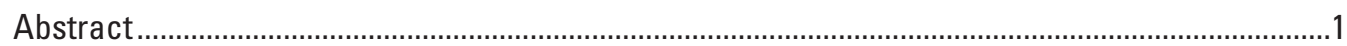

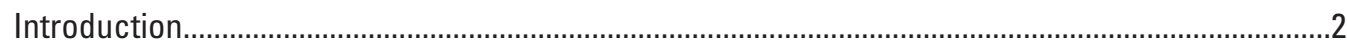

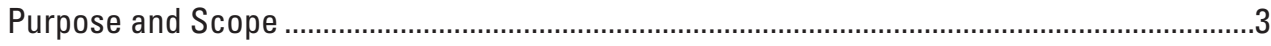

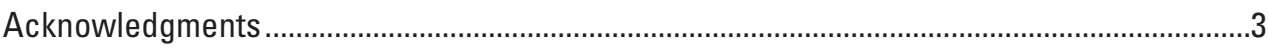

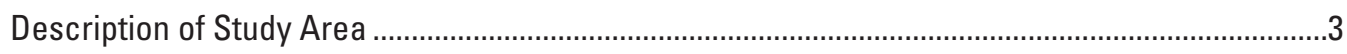

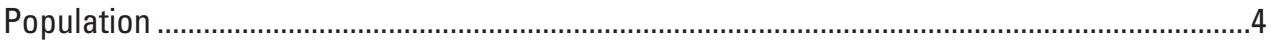

Land Use / Land Cover ........................................................................................................

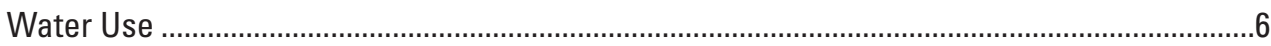

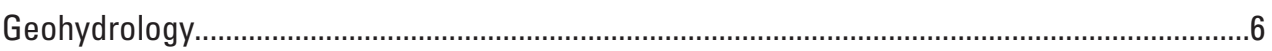

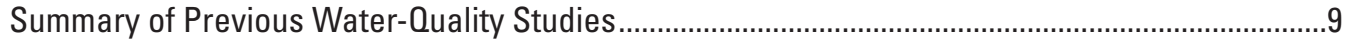

Water-Quality Assessment of the High Plains Aquifer..................................................................14

Chapter 1. Sources-Quality of Recently Recharged Water in the High Plains Aquifer, by Kevin F. Dennehy, Jason J. Gurdak, Peter B. McMahon, Jennifer S. Stanton, and Sharon L. Qi .................................................................................21

Chapter 2. Transport-Linking the Chemistry of Recharge and the Used Resource in the High Plains Aquifer, by Peter B. McMahon and John Karl Böhlke ............................49

Chapter 3. Receptors-Quality of the Used Resource in the High Plains Aquifer, by Breton W. Bruce, Jason J. Gurdak, and Peter B. McMahon .........................................73

Chapter 4. Water Quality and the Availability and Sustainability of Water Supplies in the High Plains Aquifer, by Kevin F. Dennehy, Peter B. McMahon, Jason J. Gurdak, and Breton W. Bruce ............................................................................... 107

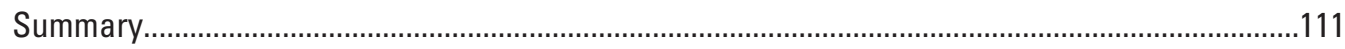

Selected References.....................................................................................................................113

Appendix 1. Reports published as part of, or in cooperation with, the High Plains Regional Ground-Water study... 122

Appendix 2. Water Quality of the High Plains Aquifer in a National Context....... 


\section{Contents}

(Introductory figures and tables)

\section{Figures}

1. Map showing location of the High Plains aquifer ..........................................................2

2. Map showing the distribution of mean annual air temperature in the High Plains ........ 3

3. Map showing the distribution of mean annual precipitation in the High Plains ................4

4. Graph showing changes in population in the High Plains, by subregion, 1900 to 2000

5. Maps showing $(A)$ Land use/land cover in the High Plains aquifer area, nominal date 2000 and $(B)$ distribution of irrigated cropland in the High Plains aquifer area, nominal date 1992

6-9. Graphs showing:

6. Total harvested acreage for primary crops grown in the High Plains, 1949 to 2002

7. Total number of reported cattle, calves, and swine in the High Plains,

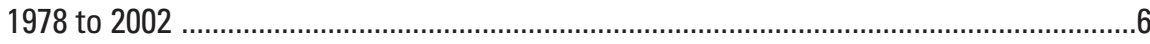

8. Primary uses of ground water pumped from the High Plains aquifer in 2000 .............6

9. (A) Ground-water pumping from the High Plains aquifer for irrigation, 1949 to 2000. (B) Acreage of irrigated cropland in the High Plains, 1949 to 2002

10-16. Maps showing:

10. $(A)$ hydrogeologic units of the High Plains aquifer and $(B)$ geologic units underlying the High Plains aquifer.

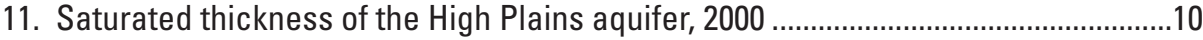

12. Depth to the regional water table in the High Plains aquifer, 2000 .............................10

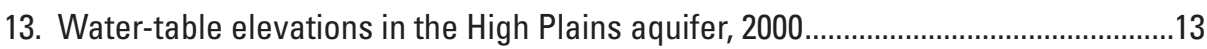

14. Water-level changes in the High Plains aquifer, predevelopment to 2005 ................13

15. Example of the stratification process used for the central High Plains subregion in the High Plains Regional Ground-Water study.......................................18

16. Nested design used in the central High Plains subregion.........................................19

17. Schematic representation of the holistic monitoring design used in the High

Plains Regional Ground-Water study

\section{Tables}

1. Generalized section of geologic units in the High Plains .....

2. Summary of selected water-quality studies previously conducted within the

High Plains study area

3. Stratification scheme used in the High Plains Regional Ground-Water Study ..................15

4. Primary components of the High Plains Regional Ground-Water study...........................16 


\section{Conversion Factors, Abbreviations, Acronyms, and Datums}

Inch/Pound to SI

\begin{tabular}{|c|c|c|}
\hline Multiply & By & To obtain \\
\hline \multicolumn{3}{|c|}{ Length } \\
\hline inch & 2.54 & centimeter $(\mathrm{cm})$ \\
\hline inch & 25.4 & millimeter (mm) \\
\hline foot $(\mathrm{ft})$ & 0.3048 & meter $(\mathrm{m})$ \\
\hline mile (mi) & 1.609 & kilometer $(\mathrm{km})$ \\
\hline \multicolumn{3}{|c|}{ Area } \\
\hline acre & 0.4047 & hectare (ha) \\
\hline acre & 0.004047 & square kilometer $\left(\mathrm{km}^{2}\right)$ \\
\hline square mile $\left(\mathrm{mi}^{2}\right)$ & 259.0 & hectare (ha) \\
\hline square mile $\left(\mathrm{mi}^{2}\right)$ & 2.590 & square kilometer $\left(\mathrm{km}^{2}\right)$ \\
\hline \multicolumn{3}{|c|}{ Volume } \\
\hline gallon (gal) & 3.785 & liter (L) \\
\hline million gallons (Mgal) & 3,785 & cubic meter $\left(\mathrm{m}^{3}\right)$ \\
\hline acre-foot (acre-ft) & 1,233 & cubic meter $\left(\mathrm{m}^{3}\right)$ \\
\hline \multicolumn{3}{|c|}{ Flow rate } \\
\hline gallon per day (gal/d) & 0.003785 & cubic meter per day $\left(\mathrm{m}^{3} / \mathrm{d}\right)$ \\
\hline million gallons per day (Mgal/d) & 0.04381 & cubic meter per second $\left(\mathrm{m}^{3} / \mathrm{s}\right)$ \\
\hline inch per year (in/yr) & 25.4 & millimeter per year (mm/yr) \\
\hline \multicolumn{3}{|c|}{ Mass } \\
\hline pound, avoirdupois (lb) & 0.4536 & kilogram $(\mathrm{kg})$ \\
\hline
\end{tabular}




\section{Frequently Used Abbreviations and Acronyms}

$\begin{array}{ll}\text { CHP } & \text { Central High Plains } \\ \text { HPGW } & \text { High Plains Regional Ground-Water study } \\ \text { MCL } & \text { Maximum Contaminant Level } \\ \text { NAWQA } & \text { National Water-Quality Assessment Program } \\ \text { NHP } & \text { Northern High Plains } \\ \text { SHP } & \text { Southern High Plains } \\ \text { SMCL } & \text { Secondary Maximum Contaminant Level } \\ \text { USEPA } & \text { U.S. Environmental Protection Agency } \\ \text { USGS } & \text { U.S. Geological Survey }\end{array}$

Temperature in degrees Celsius $\left({ }^{\circ} \mathrm{C}\right)$ may be converted to degrees Fahrenheit $\left({ }^{\circ} \mathrm{F}\right)$ as follows: ${ }^{\circ} \mathrm{F}=\left(1.8 x^{\circ} \mathrm{C}\right)+32$

Temperature in degrees Fahrenheit $\left({ }^{\circ} \mathrm{F}\right)$ may be converted to degrees Celsius $\left({ }^{\circ} \mathrm{C}\right)$ as follows: ${ }^{\circ} \mathrm{C}=\left({ }^{\circ} \mathrm{F}-32\right) / 1.8$

Vertical coordinate information is referenced to the National Geodetic Vertical Datum of 1929 (NGVD 29).

Horizontal coordinate information is referenced to the North American Datum of 1983 (NAD 83).

Elevation, as used in this report, refers to distance above the vertical datum. 


\title{
Water-Quality Assessment of the High Plains Aquifer, 1999-2004
}

\author{
By Peter B. McMahon, Kevin F. Dennehy, Breton W. Bruce, Jason J. Gurdak, and Sharon L. Oi
}

\section{Abstract}

Water quality of the High Plains aquifer was assessed for the period 1999-2004 as part of the U.S. Geological Survey's National Water-Quality Assessment (NAWQA) Program. This effort represents the first systematic regional assessment of water quality in this nationally important aquifer. A stratified, nested group of studies was designed to assess linkages between the quality of water recharging the aquifer, the effect of transport through the hydrologic system on water quality, and the quality of the resource used for human consumption and agricultural applications. The stratified, nested design facilitated upscaling of monitoring results to unmonitored areas of the aquifer as well as upscaling of process understanding from local to regional scales.

Irrigated cropland was a direct or indirect source of salts, nitrate, and pesticides in recent recharge (less than 50 years old) to the High Plains aquifer. Urban land was also a source of those constituents, as well as volatile organic compounds, although urban development is much less widespread than agriculture in the High Plains. Processes that promote recharge in this semiarid area, such as irrigation, increase the potential for ground-water contamination by increasing chemical fluxes and decreasing chemical transit times to the water table. Furthermore, conversion of rangeland to irrigated cropland has the potential to mobilize large natural salt deposits in the unsaturated zone that could eventually reach the water table.

Once water recharges the aquifer, it is transported in response to hydraulic gradients to downgradient receptors such as domestic, public-supply, and irrigation wells. During transport, the chemistry of recharge changes as a result of three primary processes-water/rock interactions, redox processes, and mixing of water from different sources. Water/ rock interactions and redox processes in the High Plains aquifer are, for the most part, natural processes that result in small changes in the concentrations of dissolved constituents. Denitrification, the redox process that is perhaps most relevant to drinking-water quality in the aquifer because of relatively widespread nitrate contamination, generally cannot be relied upon to substantially attenuate nitrate contamination because it occurs very slowly in most areas of the aquifer. Locally, and in some cases in larger areas, however, denitrification was an important attenuating mechanism. Mixing occurs naturally in the aquifer, particularly in some river valleys that are major discharge areas. In some of those discharge areas, brackish waters from underlying formations enter the High Plains aquifer and mix with fresh ground water. Mixing also is caused by leakage through long well screens and by long-term pumping of high-capacity public-supply and irrigation wells. Mixing caused by leakage and pumping is considered to be a major process for moving contaminants from near the water table to deeper zones more rapidly than would occur otherwise under natural hydraulic gradients. Thus, anthropogenic activity not only can be a source of contaminants to the water table, but it can also enhance their transport once they are in the aquifer. Pumping wells also can induce brackish water from underlying formations to move into the aquifer. Those shallow and deep mixing processes could eventually limit the availability of high-quality water to zones near the middle of the aquifer.

The quality of water produced by domestic, publicsupply, and irrigation wells in the High Plains aquifer generally was acceptable for most uses, although differences in water quality among the assessed hydrogeologic units and among well types were observed. Evaluation of domestic-well water quality on the basis of exceedances of national primary and secondary drinking-water standards indicates that water from the Ogallala Formation in the southern High Plains had the poorest quality, followed by water from the Quaternary and Plio-Pleistocene deposits. The Ogallala Formation in the central and northern High Plains had the best water quality on the basis of this analysis. Most exceedances of primary and secondary drinking-water standards were those for arsenic, dissolved solids, fluoride, iron, manganese, and nitrate. The most frequently detected pesticide compounds were atrazine and deethylatrazine, whereas the most frequently detected volatile organic compound was chloroform. None of the pesticide compounds or volatile organic compounds exceeded a primary drinking-water standard.

The quality of water from some domestic and publicsupply wells was adversely affected by agricultural and urban contaminants in recent recharge and by mixing processes caused by leakage through long well screens and long-term pumping of high-capacity public-supply and irrigation wells. The combination of those processes resulted in small but measurable increases in concentrations of anthropogenic contaminants such as nitrate in High Plains ground water when viewed 
in the context of decadal and millennial timeframes. One consequence of gradual upward trends in contaminant concentrations is that the contamination problem may go undetected because of a lack of long-term monitoring data. Once contaminated, deep zones in the aquifer in which production wells are screened are not likely to be remediated quickly because of slow recharge rates, long water residence times in the aquifer, and slow rates of contaminant degradation.

The availability and sustainability of water supplies in the High Plains aquifer are influenced by many factors, one of which is water quality. This water-quality assessment establishes a regional baseline against which water-quality conditions can be tracked over time and provides process-level understanding to help explain changes. Without process-level understanding to inform the decision-making process, effective best-management practices or remediation strategies are less likely to be developed to address water-quality problems.

\section{Introduction}

The High Plains aquifer is a nationally important water resource that underlies about $174,000 \mathrm{mi}^{2}$ in parts of eight western States (fig. 1). The aquifer serves as the primary source of drinking water for most residents of the region, and

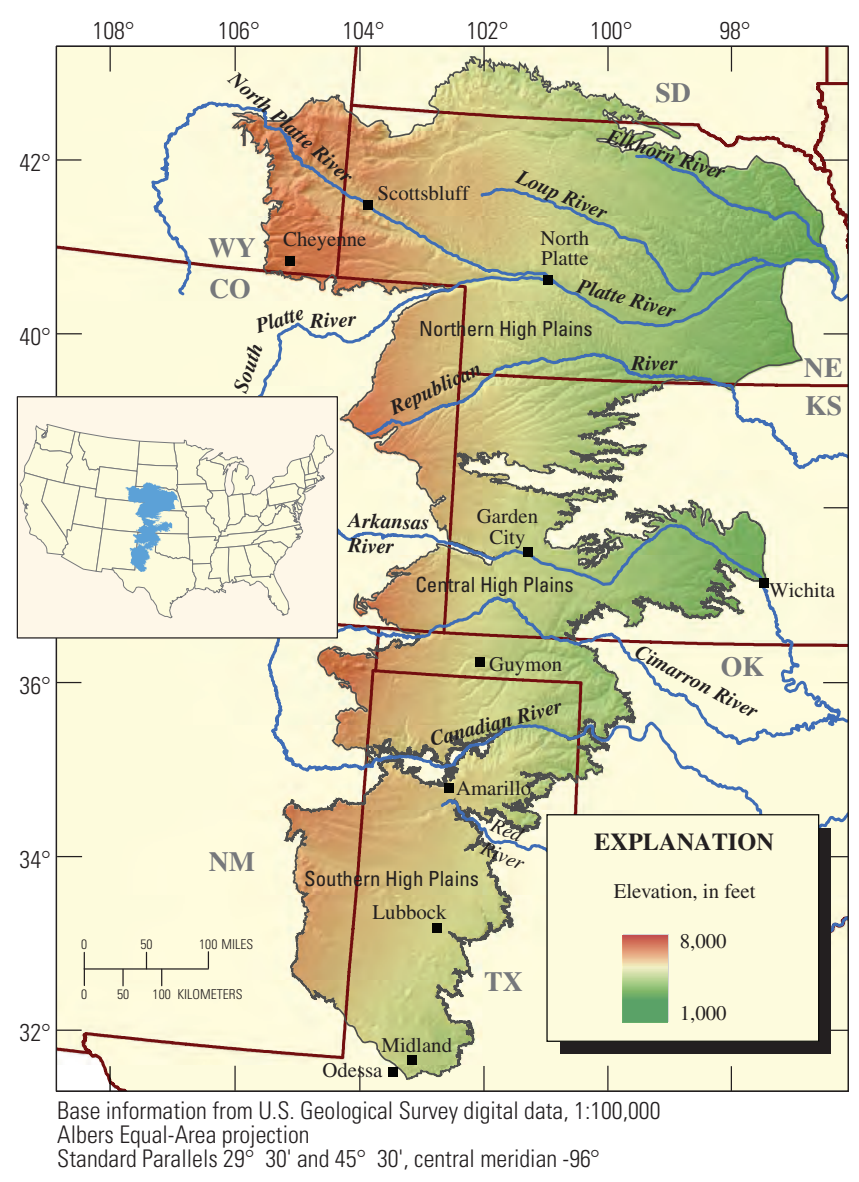

Figure 1. Location of the High Plains aquifer. it also sustains more than one-fourth of the Nation's agricultural production. Understanding water-quality conditions and the natural and human factors that control water quality in this aquifer is important because of the implications for human health, the sustainability of water supply and rural agricultural economies, and the substantial costs associated with land and water management, conservation, and regulation.

During the 1980s, the U.S. Geological Survey's (USGS) Regional Aquifer-System Analysis (RASA) Program characterized the hydrogeology of the High Plains aquifer and developed numerical models of ground-water flow to forecast changes in water storage caused by pumping (Weeks and others, 1988). That work established the benchmark for water quantity and water supply in this important aquifer against which regional changes could be compared, and the USGS continues to monitor the amount of water stored in the aquifer (McGuire, 2007). Information on the quality of water within an aquifer system is complementary to understanding the quantity of available water. It is the combination of water quantity and quality in an aquifer that determines what uses the ground-water resource can sustain. Prior to this study, there had been no comprehensive assessment of water quality in the aquifer that could serve as a baseline against which regional changes in quality could be compared.

The USGS National Water-Quality Assessment (NAWQA) Program is designed to provide a comprehensive assessment of the status, trends, and factors controlling waterquality conditions in the Nation's streams and aquifers (Gilliom and others, 1995; Gilliom, 2001). Full implementation of the NAWQA Program began in 1991. During its first cycle of studies, NAWQA delineated study-area boundaries primarily on the basis of surface-water drainages. That approach was effective for assessing surface-water resources and relatively small aquifers, but it was not necessarily suitable for understanding the water quality in regional aquifer systems that underlie multiple surface-water drainages, such as the High Plains aquifer. Understanding water-quality conditions in regional aquifer systems is complicated by spatial variability in the controlling factors inherent in regional studies and by temporal variability in recharge that may span thousands of years. Studies designed to assess water quality in regional aquifers need to account for that variability. In 1998, the NAWQA Program selected the High Plains aquifer as a pilot for assessing water quality based on a regional aquifer system approach. The effort is referred to as the High Plains Regional Ground-Water (HPGW) study. The foundation for the HPGW study was a 6-year, high-intensity phase of water-quality data collection that occurred from 1999 to 2004.

The HPGW study design is discussed in detail in the section "Water Quality Assessment of the High Plains Aquifer," and is briefly introduced here. Studies were designed to assess linkages between the quality of water recharging the aquifer (Source), the effect of transport through the hydrologic system on water quality (Transport), and the quality of the used resource as represented by water pumped from domestic, public-supply, and irrigation wells (Receptors). When these 
study components (Source, Transport, and Receptor) are combined, they form what is known as a Source-TransportReceptor (STR) model for water-quality assessments. Within this model, studies were designed to address the NAWQA goals of water-quality assessment (status or baseline) and process understanding. The process component included the study of critical processes or factors of regional importance such as recharge, ground-water flow directions and ages, and gradients in land use/land cover and climate that helped to explain baseline conditions. A stratified, nested well network was designed within the STR model that facilitated up-scaling of monitoring (assessment) results to unmonitored areas of the aquifer as well as up-scaling of process understanding from local to regional scales.

\section{Purpose and Scope}

This report summarizes the results of a 6-year intensive field effort to assess water-quality conditions and understand the natural and human factors that control water quality in the High Plains aquifer. Results presented in this report are largely a synthesis of findings previously reported in more than 25 interpretive scientific reports prepared by the USGS and its cooperators under the auspices of the HPGW study or by other individuals working in collaboration with the HPGW study (Appendix 1). The introductory sections of this report provide a description of the study area and a review of previous waterquality studies in the High Plains. The section "Water-Quality Assessment of the High Plains Aquifer" includes a description of the study design and four chapters that summarize results of the study. Chapter 1 discusses the chemical quality of recharge to the aquifer and natural and human factors affecting that quality (Source). Chapter 2 discusses ground-water residence times and chemical reactions along flow paths from recharge areas to downgradient wells in the aquifer (Transport). Chapter 3 uses the source and transport information as the basis for assessing the quality of water from domestic, public-supply, and irrigation wells in the aquifer (Receptor). Finally, Chapter 4 discusses implications of the water-quality findings with respect to water availability and sustainability of the aquifer.

\section{Acknowledgments}

The cooperation of landowners who agreed to the installation and long-term operation of monitoring wells on their property is gratefully acknowledged. This study benefited substantially from scientific collaborations with the Colorado Department of Agriculture (Daniel Hurlbut), Kansas Geological Survey (Marios Sophocleous and Margaret Townsend), Nebraska Conservation and Survey Division (James Goeke), Nebraska Cooperative Hydrology Study (Clint Carney), and the Texas Bureau of Economic Geology (Bridget Scanlon and Robert Reedy). Several USGS offices were instrumental in providing guidance and scientific and field support during the 6-year high-intensity phase: Larry (Mike) Pope and
Cristi Hansen (USGS Kansas Water Science Center), Virginia (Ginny) McGuire (USGS Nebraska Water Science Center), Mark Becker and Scott Christenson (USGS Oklahoma Water Science Center), Lynn Fahlquist (USGS Texas Water Science Center), the USGS Central Region Drilling Team, and Kevin Ellett (USGS California Water Science Center). Lisa Faust prepared the graphics in figure 57. Pixie Hamilton, James LaBaugh, Gary Rowe, and Gregory Steele provided constructive reviews of earlier versions of this report.

\section{Description of Study Area}

The study area encompasses the High Plains aquifer, which underlies about $174,000 \mathrm{mi}^{2}$ in parts of eight western States (Colorado, Kansas, Nebraska, New Mexico, Oklahoma, South Dakota, Texas, Wyoming) (fig. 1). The study area was divided into three geographic subregions (fig. 1): northern High Plains (NHP) $\left(96,500 \mathrm{mi}^{2}\right)$; central High Plains (CHP) $\left(48,500 \mathrm{mi}^{2}\right)$; and southern High Plains (SHP) $\left(29,000 \mathrm{mi}^{2}\right)$. The subregions are based on considerations of the aquifer boundaries (fig. 1), regional temperature gradients (fig. 2) that affect agricultural practices, recharge, and thus water quality, and the logistics of conducting field activities across such a large area.

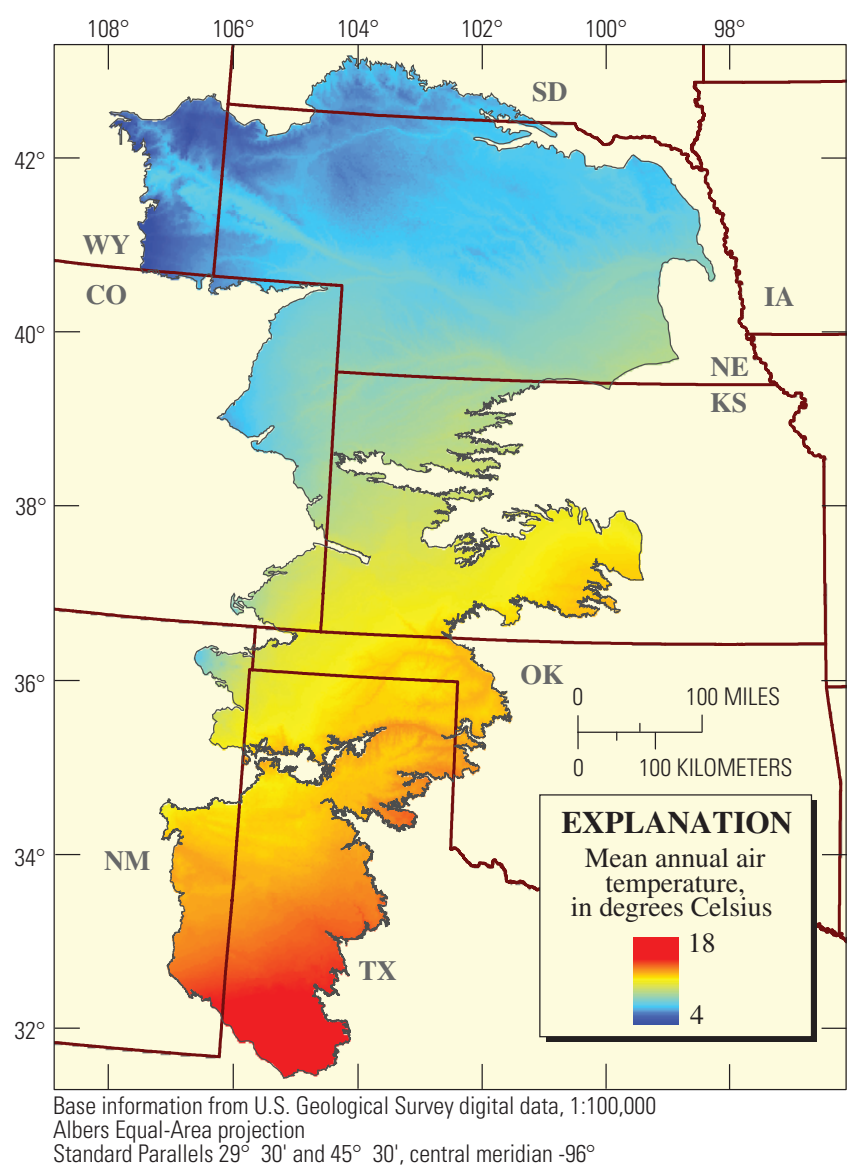

Figure 2. The distribution of mean annual air temperature in the High Plains (Thornton and others, 1997). 
The study area occupies the higher elevations of the Great Plains physiographic province, which lies between the Central Lowlands on the east and the Rocky Mountains on the west. Elevations range from about $1,000 \mathrm{ft}$ along the eastern boundary to about $8,000 \mathrm{ft}$ along the northwestern boundary of the study area (fig. 1). The topography is characterized mostly by flat to gently rolling terrain, a remnant of a vast plain of sediments deposited by streams of the ancestral Rocky Mountains. Erosion has isolated the High Plains and formed escarpments in many areas that largely coincide with the study area boundaries.

Climate of the study area is characterized as a middlelatitude, dry continental climate with abundant sunshine, moderate precipitation, frequent winds, low humidity, and a high rate of evaporation. The large areal extent of the High Plains results in temperature and precipitation gradients across the study area (figs. 2 and 3). Variation in mean annual air temperature is greatest trending north to south across the study area, ranging from about $4^{\circ} \mathrm{C}\left(39.2^{\circ} \mathrm{F}\right)$ in the NHP to $18^{\circ} \mathrm{C}\left(64.4^{\circ} \mathrm{F}\right)$ in the SHP (fig. 2). Variation in mean annual precipitation is greatest trending west to east (fig. 3), ranging from about 12 inches in the western part of the study area to 33 inches in the east. About 75 percent of the annual rainfall occurs between April and September (Dennehy and others, 2002). Much of the rainfall occurs as local convective thunderstorms, creating notable temporal and geographic variability in rainfall patterns (Dennehy and others, 2002). Snow is more common in the northern part of the study area. Evaporation rates in the High Plains range from about 60 inches in the NHP to 109 inches in the SHP (Gutentag and others, 1984) and are among the highest in the United States because of high summer air temperatures and persistent winds. In general, the daily air temperature reaches $32^{\circ} \mathrm{C}\left(90^{\circ} \mathrm{F}\right)$ or higher for about 40 days/yr in the NHP to 100 days/yr in the SHP (High Plains Regional Climate Center, 2007; Southern Regional Climate Center, 2007). The average annual sustained-peak daily windspeed for most of the study area exceeds $12 \mathrm{mi} / \mathrm{hr}$ and reaches 16 to $18 \mathrm{mi} / \mathrm{hr}$ in the Texas and Oklahoma Panhandles (Thornthwaite, 1936).

\section{Population}

The population of the study area in 2000 was approximately 2.3 million people (U.S. Census Bureau, 2000a). The majority (77 percent) of this population resided in rural areas and smaller towns and cities, while only 23 percent lived in the four largest cities: Lubbock, Tex. $(199,564)$, Amarillo, Tex. (173,627), Midland, Tex. (94,996), and Cheyenne, Wyo. (53,011) (U.S. Census Bureau, 2000a). In 2000, the largest population was in the NHP, followed by the SHP and CHP (fig. 4). During the 1900s, however, the largest population increases occurred in the SHP and CHP. Throughout the 1990s, the largest population growth generally occurred in areas with larger cities or in areas along major interstate transportation corridors.

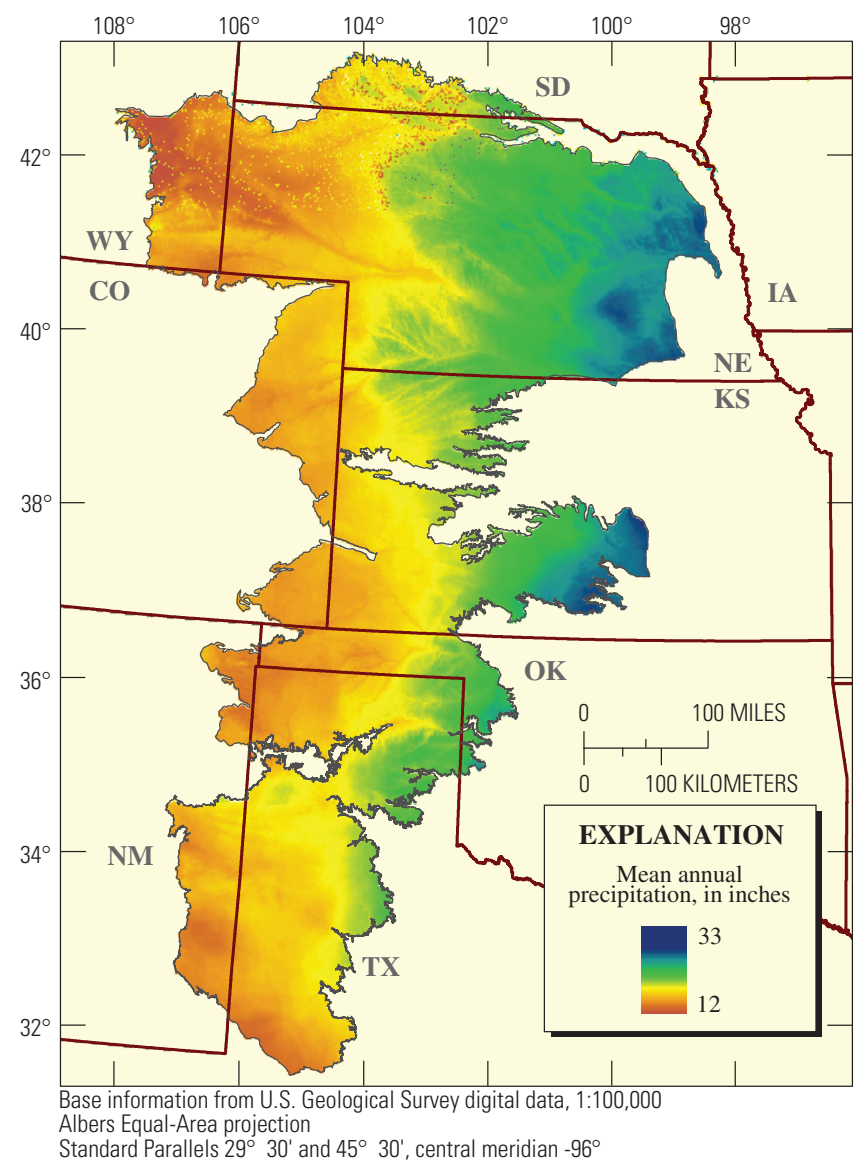

Figure 3. The distribution of mean annual precipitation in the High Plains (Thornton and others, 1997).

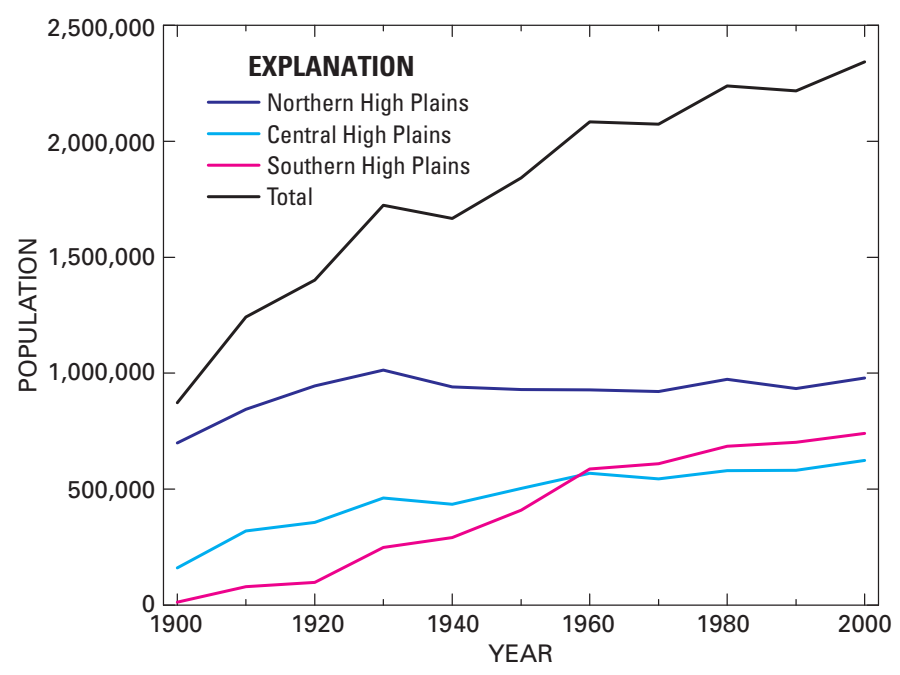

Figure 4. Changes in population in the High Plains, by subregion, 1900 to 2000 (U.S. Census Bureau, 2000a, 2000b). 


\section{Land Use / Land Cover}

The dominant land uses/land covers in the study area were rangeland and agricultural lands (National Land Cover Database, 2001) (fig. 5A). Fifty-six percent of the land was classified as rangeland (includes grasslands and shrub lands), 38 percent was agricultural land (includes cultivated crops, small grains, fallow, and pasture/hay), 3 percent was urban, and 3 percent was other land use/land cover (includes forest, water, wetland, and barren). Approximately 13.1 million acres, or 30 percent of the agricultural land, was under irrigation as of 1992 (Qi and others, 2002a). Acres under irrigation were concentrated in eastern Nebraska, southwestern Kansas, and the west-central part of the Texas Panhandle (fig. 5B).

Historically, wheat was the main crop grown in the High Plains in terms of harvested acreage, followed by corn, sorghum, hay/alfalfa, cotton, soybeans, and peanuts (fig. 6). Corn, hay/alfalfa, and soybeans are grown primarily in the NHP, wheat and sorghum primarily in the CHP, and sorghum, cotton, and peanuts are grown primarily in the SHP. In general, from 1987 to 2002, the trend in acreage for wheat

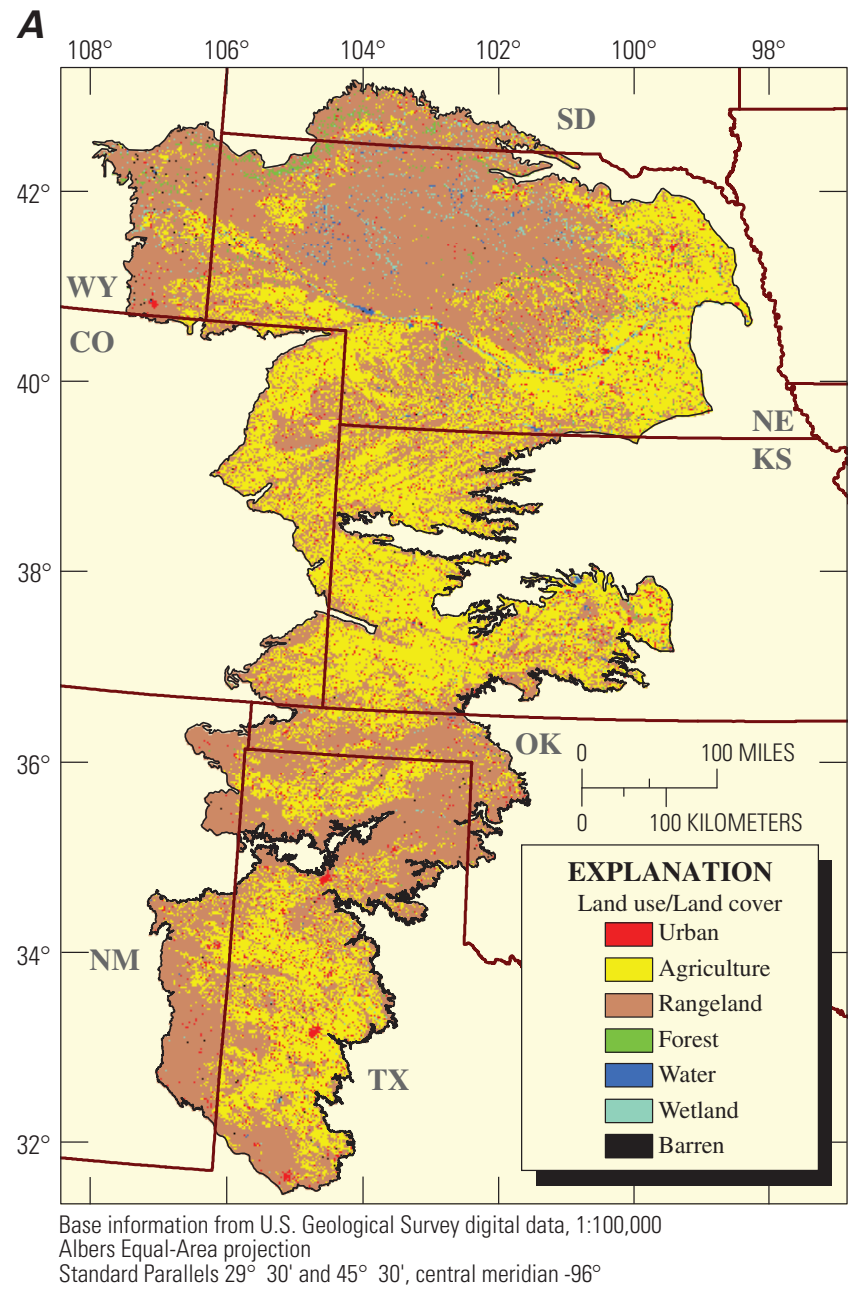

and sorghum has been downward while the trends for corn, hay/alfalfa, cotton, and peanuts have been upward, suggesting that acreages for crops with higher water requirements have increased since 1987 and the acreages for crops with lesser water requirements have decreased.

Cattle, calves, and swine are the dominant livestock in the study area. In 2002, there were approximately 14.5 million cattle and calves and 10.4 million swine (fig. 7). Estimates for swine in 2002 are conservative because 48 percent of the counties in the study area did not report to the Agricultural Census. From 1978 to 1987, the number of cattle, calves, and swine remained constant at about 12.4 million for cattle and calves and 3.2 million for swine. Cattle and calf numbers gradually increased after 1987 and peaked in 1997 at 15.4 million. The number of swine remained at approximately 3 to 4 million until 1997, but increased by 160 percent from 1997 to 2002. From 1978 to 2002, an increasing percentage of counties did not report numbers of swine to protect the information from single farms; 4 percent of counties did not report in 1978 compared to 48 percent of counties that did not report in 2002.

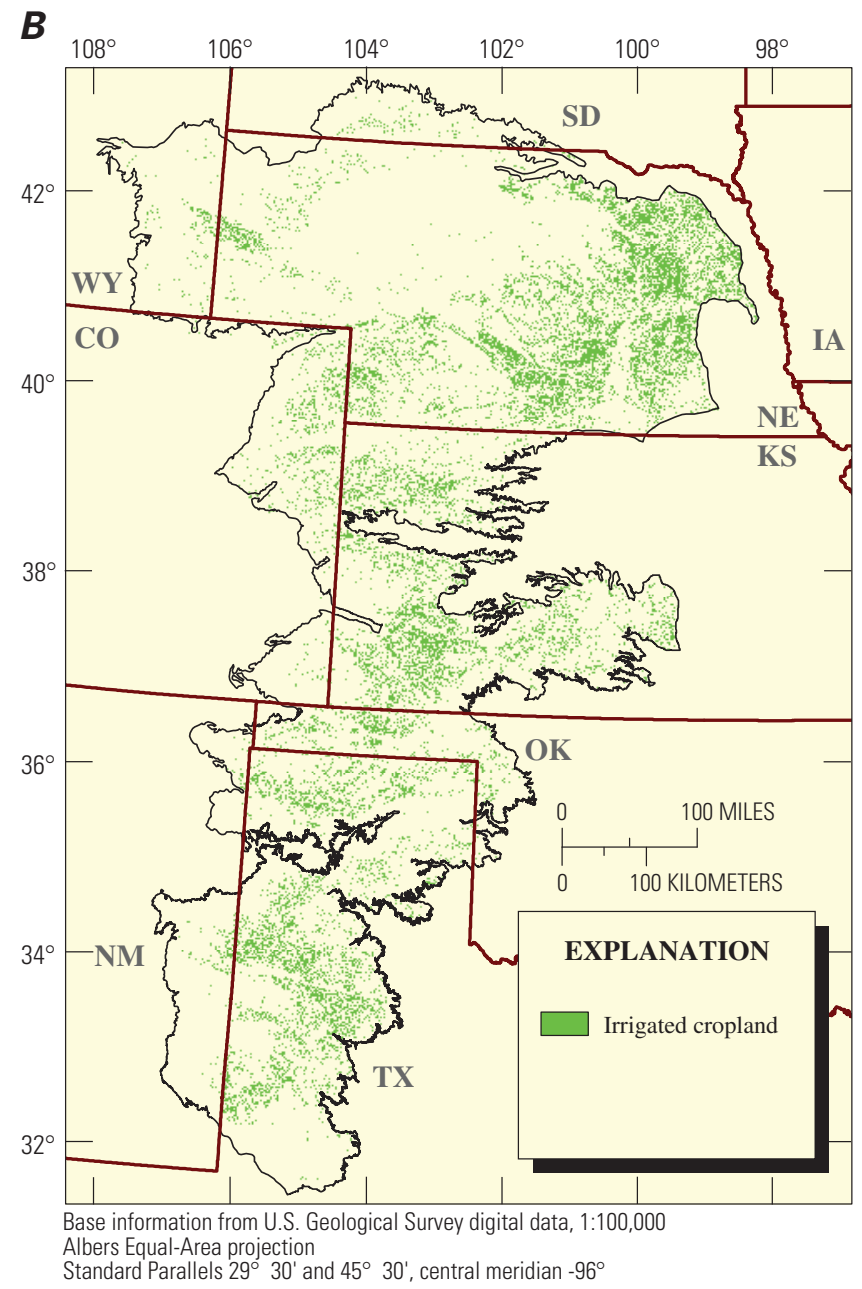

Figure 5. (A) Land use/land cover in the High Plains aquifer area, nominal date 2000 (National Land Cover Database, 2001 ) and $(B)$ distribution of irrigated cropland in the High Plains aquifer area, nominal date 1992 (Qi and others, 2002a). 


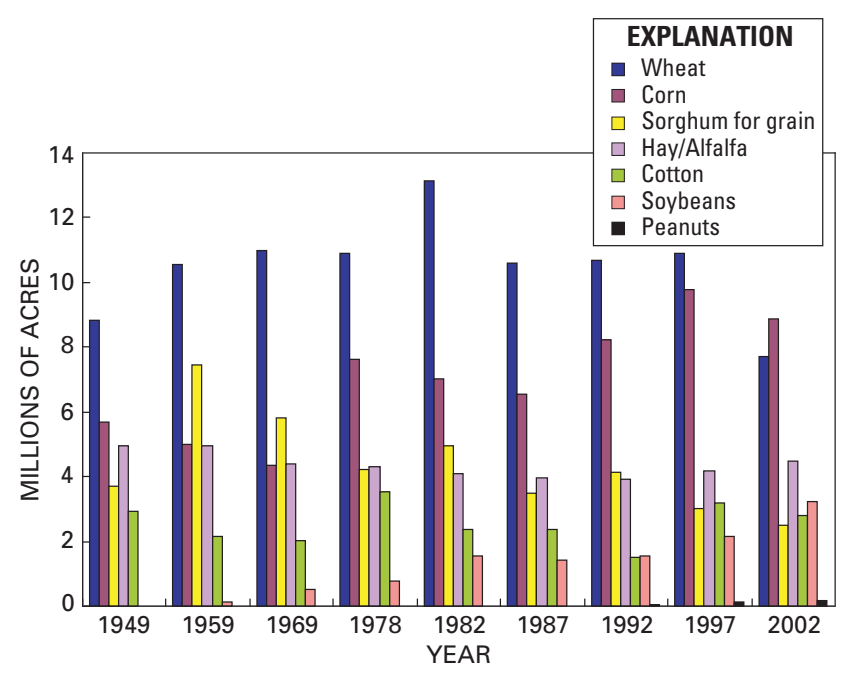

Figure 6. Total harvested acreage for primary crops grown in the High Plains, 1949 to 2002 (U.S. Department of Commerce, variously dated; U.S. Department of Agriculture, 1999, 2002).

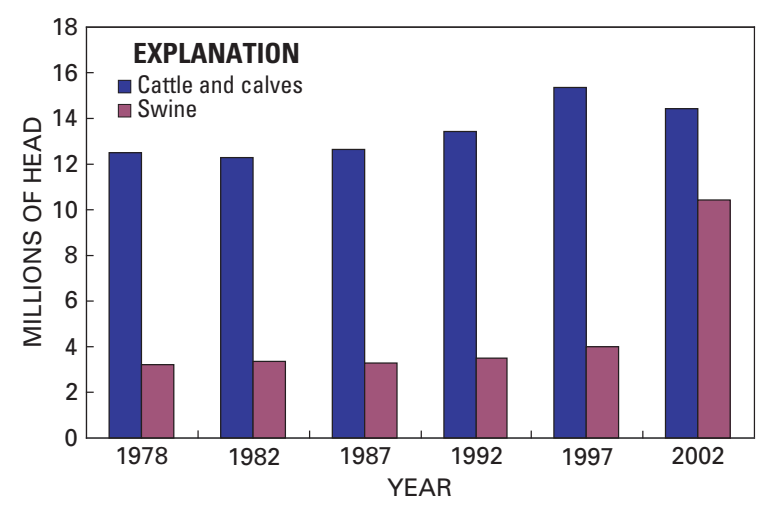

Figure 7. Total number of reported cattle, calves, and swine in the High Plains, 1978 to 2002 (U.S. Department of Commerce, variously dated; U.S. Department of Agriculture, 1999, 2002).

\section{Water Use}

In 2000, the High Plains aquifer had an estimated 2,980 million acre-ft of drainable water in storage (McGuire and others, 2003), making it one of the largest aquifers in the world (Gutentag and others, 1984). Use of the High Plains aquifer as a source of irrigation water has transformed the study area into one of largest and most productive agricultural regions, earning it the nickname "breadbasket of the world" (Opie, 2000). In 2000, withdrawals from the High Plains aquifer accounted for 21.2 percent of ground water withdrawn in the United States (Hutson and others, 2004), which makes it the most intensively used principal aquifer of the United States (Maupin and Barber, 2005). Water pumped from the aquifer was used to irrigate crops on about 27 percent of the irrigated land in the United States (Dennehy, 2000), and withdrawals amounted to 29.5 percent of the Nation's ground water used for irrigation (Maupin and Barber, 2005). The dominant water use in the study area in 2000 was irrigation (fig. 8), accounting for 97 percent $(17,000 \mathrm{Mgal} / \mathrm{d})$ of withdrawals from the aquifer, with public supply (2 percent, $389 \mathrm{Mgal} / \mathrm{d}$ ) and self-supplied industrial (1 percent, $99.2 \mathrm{Mgal} / \mathrm{d}$ ), which includes domestic use, livestock, aquaculture, mining, and thermoelectric power, accounting for smaller percentages (Maupin and Barber, 2005). Although public and domestic uses account for a relatively small percentage of the total ground-water use, these two sources provide drinking water for about 82 percent of the 2.3 million people who live within the study area boundary (Dennehy, 2000).

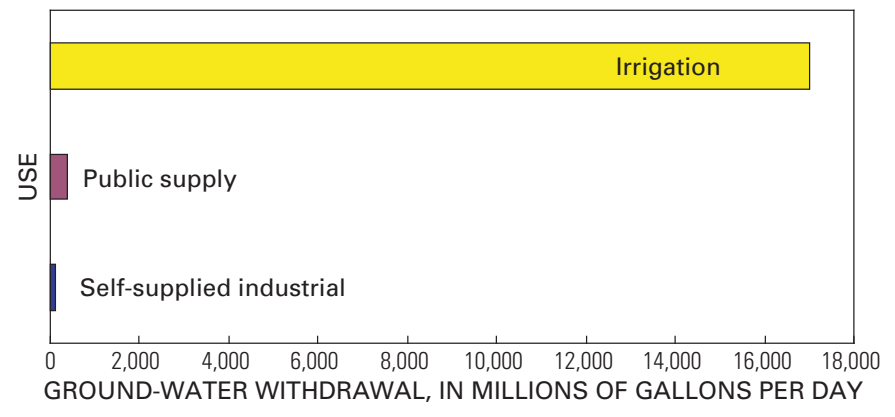

Figure 8. Primary uses of ground water pumped from the High Plains aquifer in 2000 (Maupin and Barber, 2005).

The historical development of the High Plains aquifer was driven primarily by irrigated agriculture (Dennehy and others, 2002), the importance of which is now reflected by irrigation as the dominant water use from the aquifer (fig. 8). Since the beginning of substantial pumping of ground water for irrigation in the 1940 s, pumping rates for irrigation have generally increased (fig. 9A). During the late 1970s and 1980s, however, there was a decline in ground-water pumping for irrigation, which was reflected in a decline in the total acres of irrigated agriculture (fig. 9B). During the 1990s, the study area experienced moderate growth in irrigated acres accompanied by a corresponding increase in ground-water pumpage (Dennehy and others, 2002).

\section{Geohydrology}

The High Plains aquifer consists of near-surface sedimentary deposits of Tertiary and Quaternary age (table 1). Those deposits form the six hydraulically connected hydrogeologic units of the regionally unconfined aquifer (fig. 10A) (Gutentag and others, 1984; Dennehy and others, 2002). The Tertiary sediments include parts of the Brule Formation (of the White River Group), Arikaree Group, Ogallala Formation, and alluvial deposits of Pliocene age. The deposits of Quaternary age 


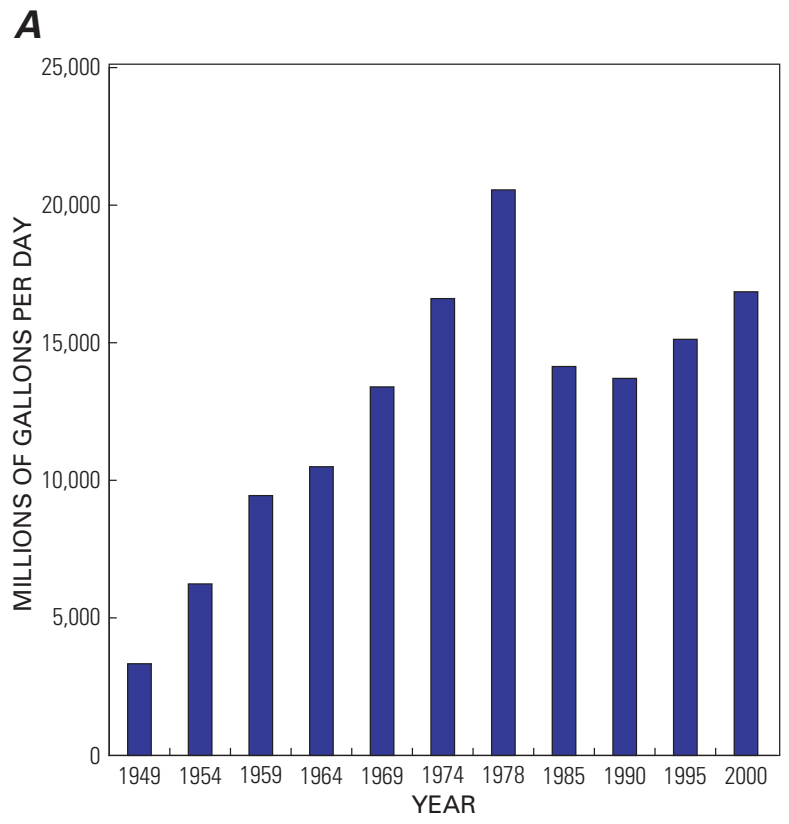

B

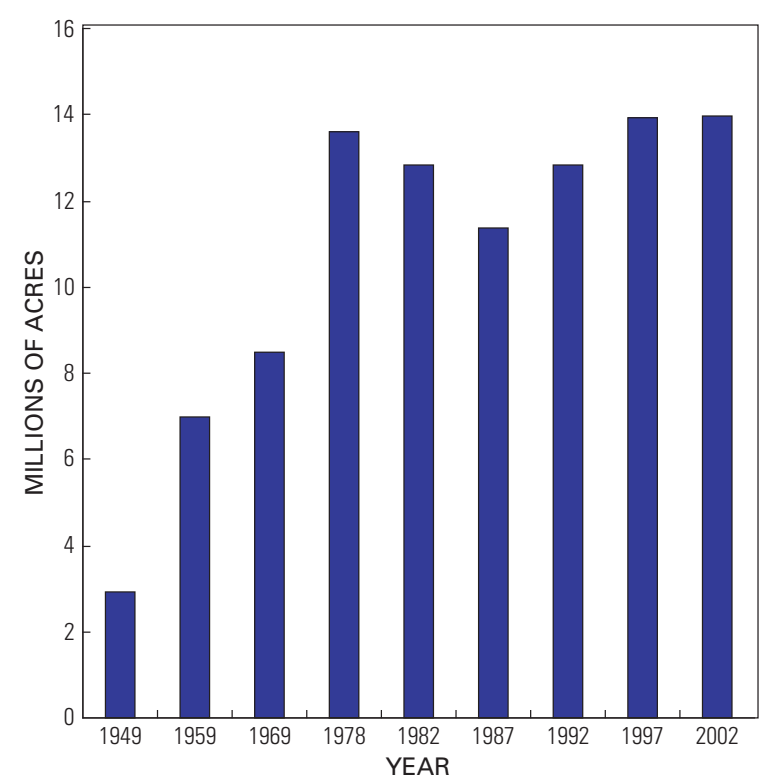

Figure 9. (A) Ground-water pumping from the High Plains aquifer for irrigation, 1949 to 2000 (Gutentag and others, 1984; U.S. Geological Survey, variously dated). $(B)$ Acreage of irrigated cropland in the High Plains, 1949 to 2002 (U.S. Department of Commerce, variously dated; U.S. Department of Agriculture, 1999, 2002).

consist of glacially derived sediments hydraulically connected to the Tertiary units (eastern Nebraska), reworked Tertiary sediments (south-central Kansas), and local alluvial, loess, dune-sand, and valley-fill deposits. Bedrock units that underlie the High Plains aquifer range in age from Permian to Tertiary (fig. 10B) (Gutentag and others, 1984). Those bedrock units are generally less permeable than sediments of the High Plains aquifer, but locally they do yield water to wells. Water in the underlying bedrock units, particularly those of Permian age, can contain large concentrations of dissolved solids that could affect the quality of water in the High Plains aquifer

The Brule Formation, located primarily in parts of Nebraska, Colorado, and Wyoming, is a massive siltstone that contains localized beds of gravel, sandstone, volcanic ash, claystone, and fine sand. The Brule Formation is considered part of the High Plains aquifer where secondary permeability has been increased by joints, fractures, and solution openings. Maximum thickness of the Brule Formation is about $600 \mathrm{ft}$.

The Arikaree Group is predominantly fine-grained sandstone that locally contains beds of volcanic ash, silty sand, and sandy clay and is located primarily in areas of Nebraska, South Dakota, and Wyoming. Maximum thickness of the Arikaree Group is about 1,000 ft.

The Ogallala Formation of Miocene age has the largest areal extent of all the geologic units in the High Plains aquifer and underlies approximately $134,000 \mathrm{mi}^{2}$ (77 percent) of the study area (Luckey and others, 1986). The Ogallala was deposited by aggrading streams that filled and buried valleys eroded into pre-Ogallala rocks. Braided streams flowing eastward from the ancestral Rocky Mountains deposited a heterogeneous sequence of clay, silt, sand, and gravel. Locally cemented zones consisting of calcium carbonate (caliche), and sometime silica, occur near the top of the formation, forming escarpments that mark the boundary of the High Plains in parts of the CHP and SHP. The caliche caprock is most prominent across much of Texas and New Mexico and is as much as 60 $\mathrm{ft}$ thick. Extensive clay layers are present locally within the saturated zone of the Ogallala Formation, sometimes causing locally confined conditions.

The deposits of Pliocene age consist of unconsolidated alluvial sands and gravels. In eastern Nebraska, these deposits are hydraulically connected to deposits of Pleistocene age. Together, those deposits are referred to as the Plio-Pleistocene deposits hydrogeologic unit (fig. 10A).

Dune-sand deposits are part of the High Plains aquifer and consist of very fine to medium-grained eolian sand. Approximately 19 percent of the study area is covered by dune sand (Gutentag and others, 1984). These areas probably represent important recharge areas because of the relatively high permeability of the sand. The most extensive area of dune sand is the Sand Hills of west-central Nebraska, referred to as the Sand Hills eolian deposits hydrogeologic unit (fig. 10A), which cover approximately $20,000 \mathrm{mi}^{2}$ and have a maximum thickness of about $300 \mathrm{ft}$.

The alluvial deposits of Quaternary age consist of gravel, sand, silt, and clay that are associated with the most recent erosion and deposition along present-day streams, particularly along the Platte, Republican, and Arkansas Rivers (fig. 1). Those deposits are referred to as the alluvial systems hydrogeologic unit (fig. 10A).

The saturated thickness of the High Plains aquifer ranges from less than $1 \mathrm{ft}$ to more than 1,000 ft (fig. 11) and averages 
Table 1. Generalized section of geologic units in the High Plains (modified from Weeks and Gutentag, 1981; Richmond and others, 1994; Gosselin and others, 1997; Stanton and Qi, 2007).

[Geologic units shaded in blue are part of the High Plains aquifer, although not all units are present in most locations]

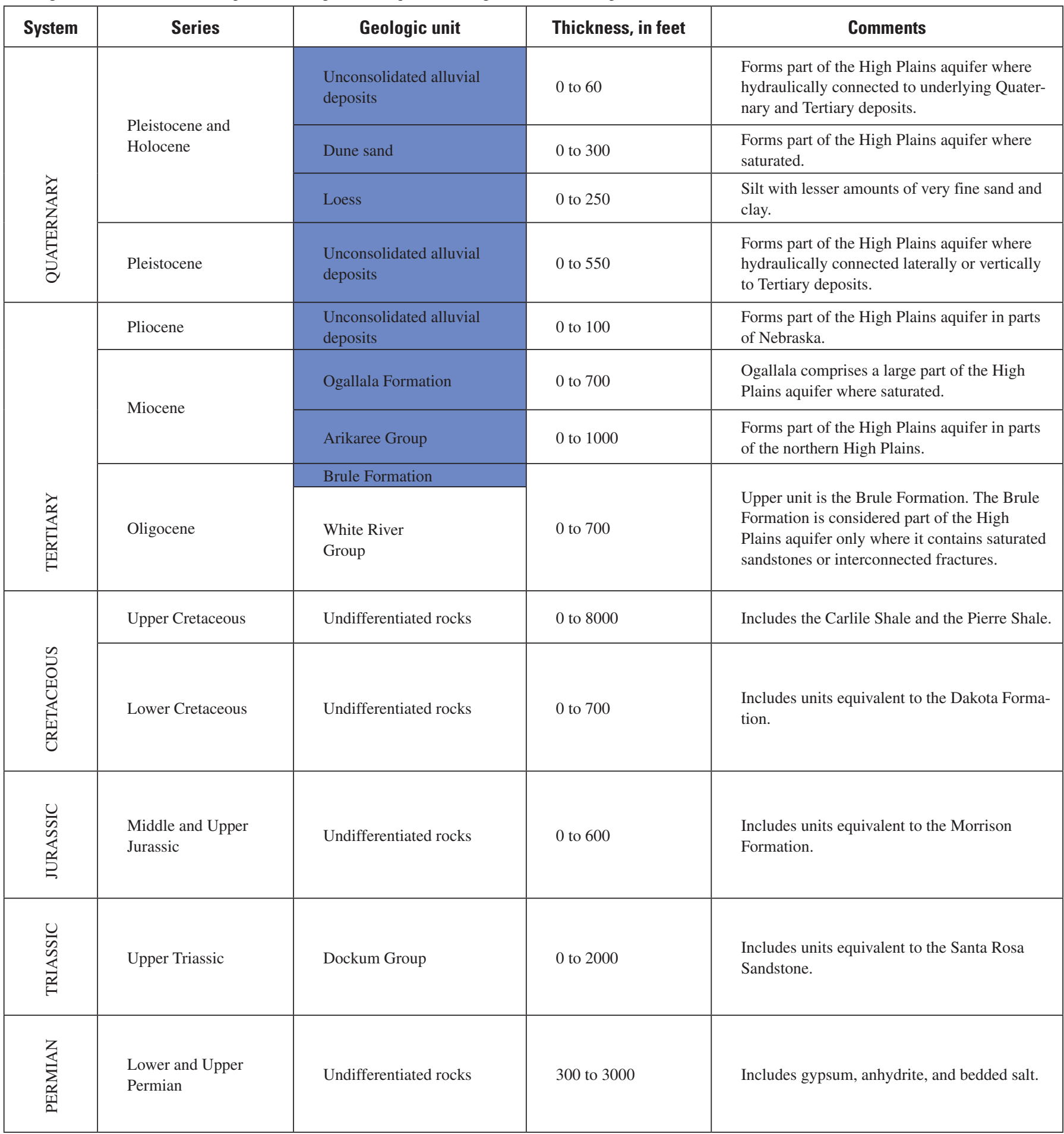



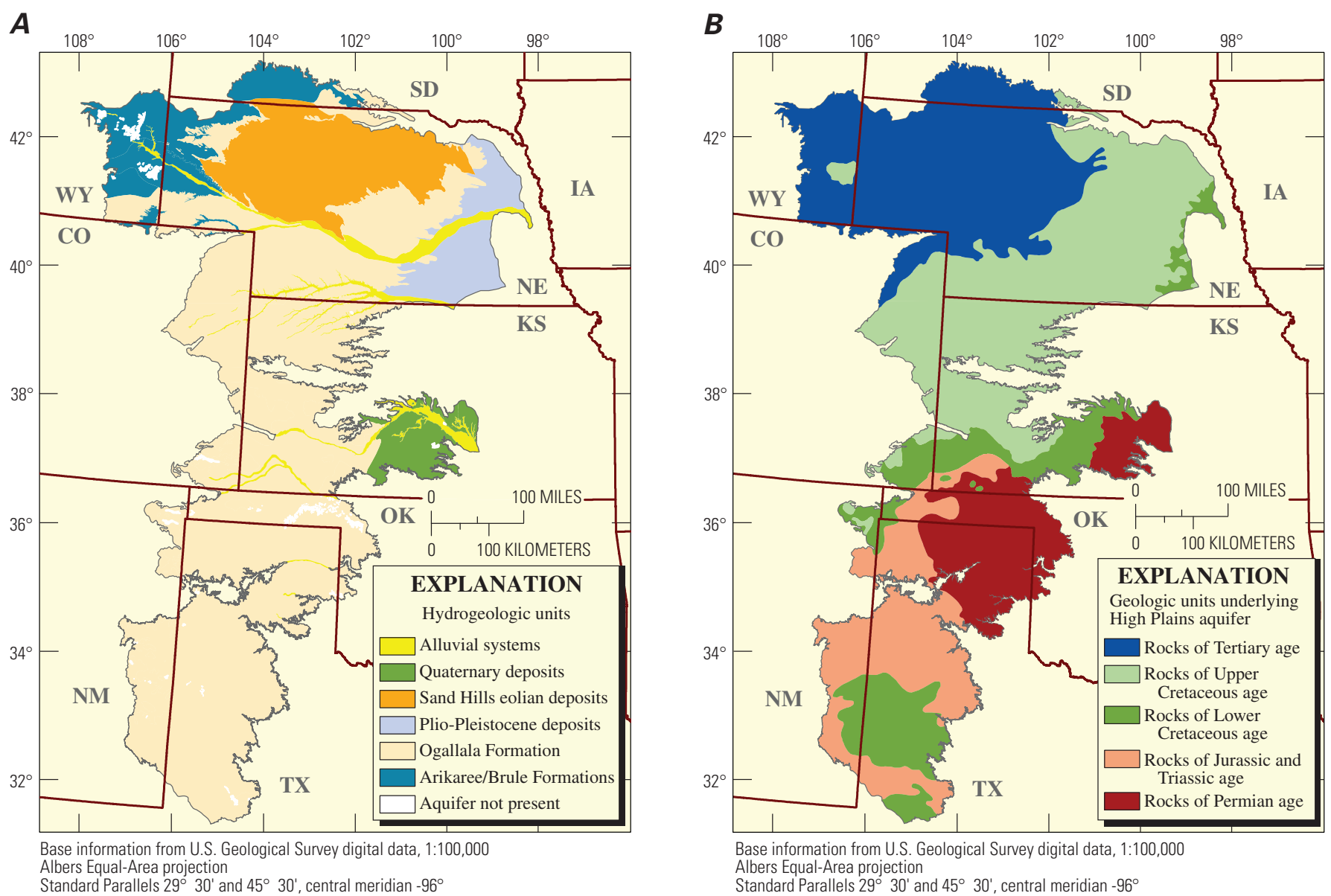

Figure 10. (A) Hydrogeologic units of the High Plains aquifer and $(B)$ geologic units underlying the High Plains aquifer.

about $200 \mathrm{ft}$. Depth to water ranges from 0 to approximately $500 \mathrm{ft}$ (fig. 12) and averages about $100 \mathrm{ft}$. Depths to water are greatest in the CHP and SHP, whereas the saturated thickness is greatest in the NHP. Water-table elevations in the High Plains aquifer indicate that regional ground-water flow is generally from west to east (fig. 13); however, local variability in hydraulic gradients can result in different directions of groundwater flow, particularly near high-capacity pumping wells and major rivers like the Platte, Republican, and Arkansas. Gutentag and others (1984) estimated, on the basis of average values of hydraulic conductivity and hydraulic gradient, that the velocity of ground-water flow in the aquifer is about $1 \mathrm{ft} / \mathrm{d}$. Because evaporation rates exceed precipitation rates across much of the study area, little water is available to recharge the aquifer. Recharge to the High Plains aquifer occurs by infiltration of irrigation water, areally diffuse infiltration from precipitation, focused infiltration of storm- and irrigationwater runoff through streambeds and other topographic depressions, and upward movement of water from underlying aquifers (McMahon, 2001). Discharge from the High Plains aquifer occurs primarily by irrigation well pumping, discharge to streams and underlying aquifers, ground-water flow across the eastern boundary of the aquifer, and evapotranspiration (Luckey and others, 1986).

Substantial water-level changes have occurred in the High Plains aquifer since predevelopment (fig. 14). The extent of water-level change is dependent in part on the relative magnitudes of discharge and recharge in the aquifer. Because ground-water withdrawals have greatly exceeded recharge rates across much of the aquifer, water-level declines are common, particularly in the SHP and CHP. The largest waterlevel declines range from 50 to more than $150 \mathrm{ft}$. These occur primarily across parts of Kansas, Oklahoma, New Mexico, and Texas (McGuire, 2007). Water-level rises since predevelopment have occurred locally, primarily in the southern one-half of the SHP, eastern parts of the CHP, and across parts of the NHP (McGuire, 2007).

\section{Summary of Previous Water-Quality Studies}

More than 100 references to water quality are listed in a bibliography of water-related studies for the High Plains 


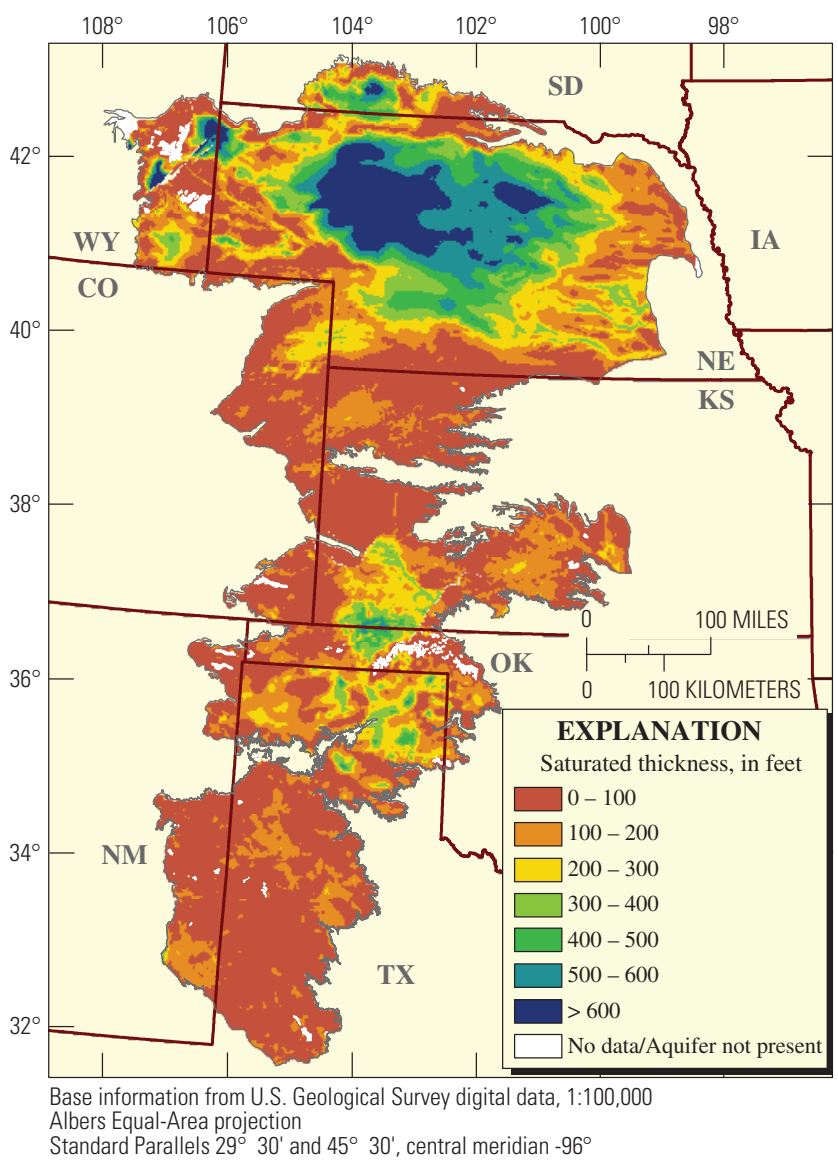

Figure 11. Saturated thickness of the High Plains aquifer, 2000 (modified from McGuire and others, 2003).

study area that was compiled as part of this study (Gerhard Kuhn, U.S. Geological Survey, written commun., 2000). The most common constituent keyword in that bibliography was nitrate (70 references), followed by dissolved solids (45 references), pesticides (37 references), radiological constituents (23 references), bacteria (13 references), organic compounds (11 references), and trace elements (8 references). The frequency of citation probably is indicative of the most common waterquality concerns within the High Plains study area.

Water-quality studies of the High Plains aquifer have been conducted at scales ranging from regional to statewide to local. Selected studies at each scale are summarized in table 2 along with environmental factors found to be related to water quality. Data from many of those studies were assembled in digital format and analyzed (Litke, 2001) to provide background information for developing the HPGW study design. Early studies focused on salinity (dissolved solids) because high salinity can affect the use of water for irrigation and because extensive irrigation can lead to increased salinity. Krothe and others (1982) estimated that dissolved-solids concentrations were in excess of $500 \mathrm{mg} / \mathrm{L}$ over 19 percent of the area of the High Plains aquifer. Areas of large dissolvedsolids concentrations were related primarily to the underlying bedrock type (Mehta and others, 2000; Whittemore, 1984, 1995 ) but also occurred in irrigated alluvial valleys where ground-water pumping caused relatively salty surface water to move into the aquifer (Whittemore, 2000a,b). A study in Texas (Reeves and Miller, 1978) related high salinity to bedrock type and to seepage from saline lakes. That Texas study was also among the first to document large nitrate concentrations in the aquifer, which were related to irrigation intensity and soil properties. A study of ground-water quality in Nebraska (Engberg, 1984) focused on major ions and dissolved solids but listed nitrate as the most pervasive potential problem constituent. In the late 1980s, water-quality surveys began to document widespread occurrences of elevated nitrate concentrations. A survey of domestic wells in Kansas (Steichen and others, 1988) reported nitrate in excess of the U.S.

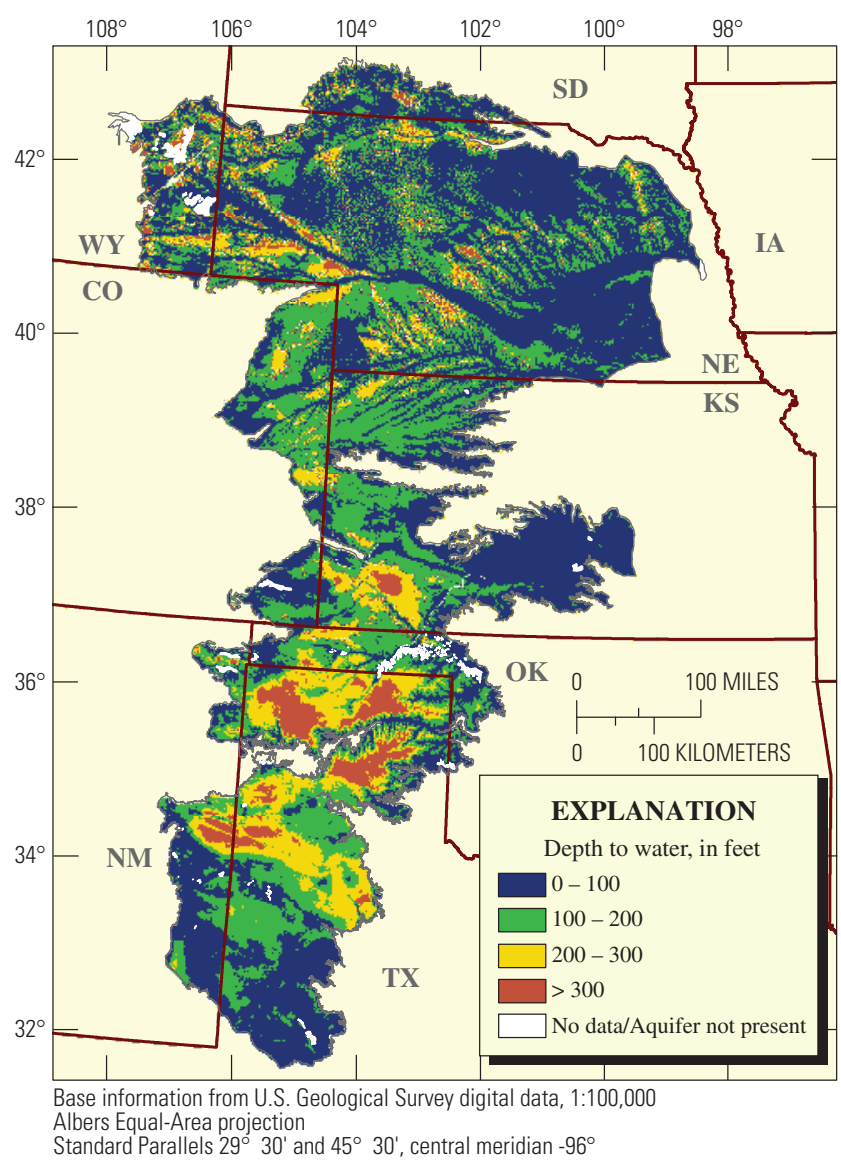

Figure 12. Depth to the regional water table in the High Plains aquifer, 2000 (V.L. McGuire, U.S. Geological Survey, written commun., 2002).

Environmental Protection Agency (USEPA) primary drinkingwater standard (Maximum Contaminant Level, MCL) of 10 $\mathrm{mg} / \mathrm{L}$ as nitrogen $(\mathrm{N})$ in 28 percent of the sampled wells (U.S. Environmental Protection Agency, 2006); and a compilation of data in Nebraska (Exner and Spalding, 1990) showed that the MCL was exceeded in 20 percent of the sampled wells. Those studies attributed large nitrate concentrations both to site- 
Table 2. Summary of selected water-quality studies previously conducted within the High Plains study area.

$[--$, not applicable $]$

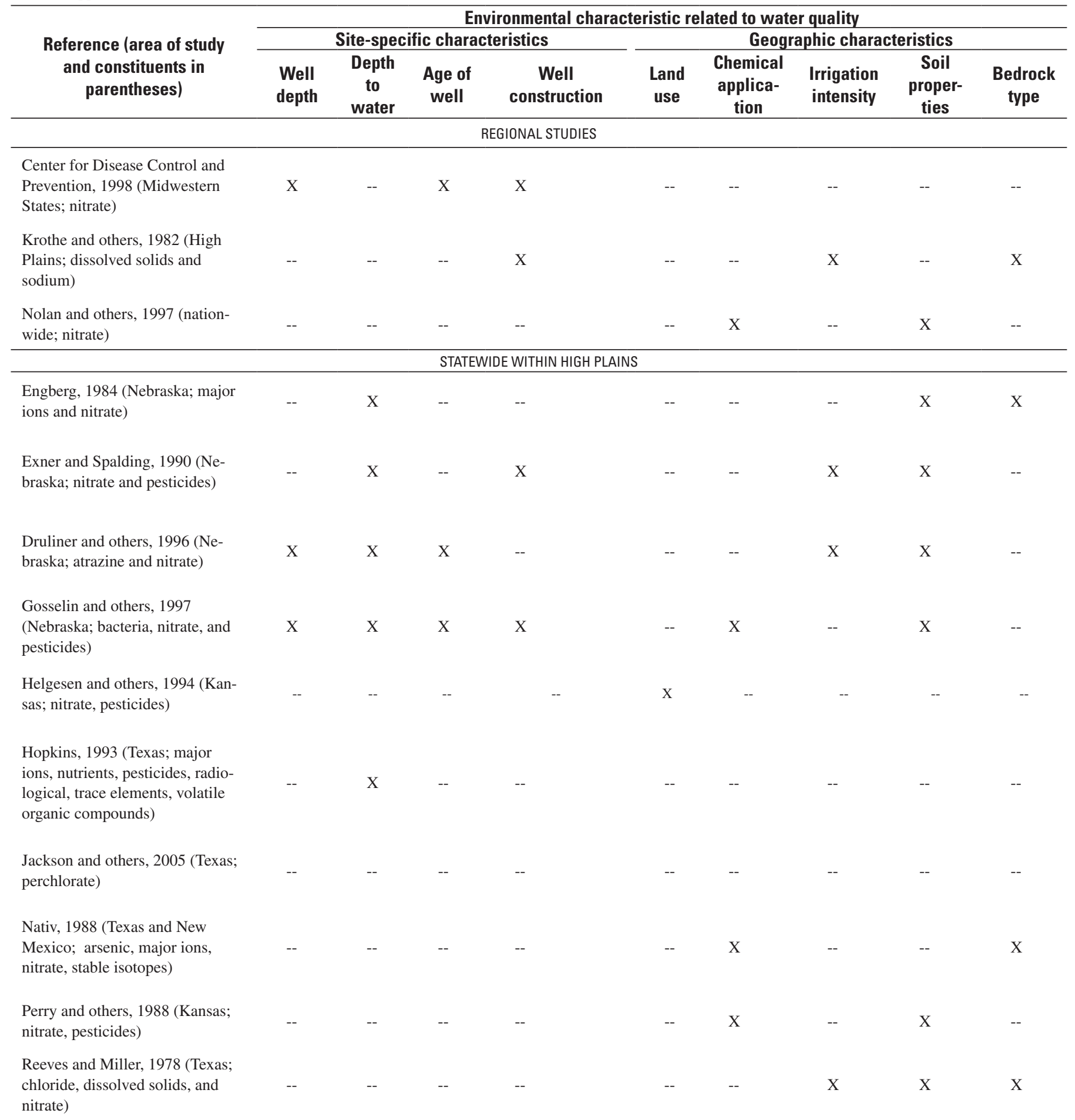


Table 2. Summary of selected water-quality studies previously conducted within the High Plains study area.-Continued

$[--$, not applicable $]$

Environmental characteristic related to water quality

\begin{tabular}{|c|c|c|c|c|c|c|c|c|c|}
\hline \multirow{2}{*}{$\begin{array}{l}\text { Reference (area of study } \\
\text { and constituents in } \\
\text { parentheses) }\end{array}$} & \\
\hline & \multicolumn{4}{|c|}{ Site-specific characteristics } & \multicolumn{5}{|c|}{ Geographic characteristics } \\
\hline \multicolumn{10}{|c|}{ LOCAL WITHIN HIGH PLAINS } \\
\hline $\begin{array}{l}\text { Fryar and others, } 2000 \text { (Texas; } \\
\text { nitrate) }\end{array}$ & $\mathrm{X}$ & $\mathrm{X}$ & -- & -- & $\mathrm{X}$ & $\mathrm{X}$ & -- & -- & -- \\
\hline $\begin{array}{l}\text { Fryar and others, } 2001 \text { (Texas; } \\
\text { major ions, nitrate, radiocarbon, } \\
\text { stable isotopes, tritium) }\end{array}$ & $\mathrm{X}$ & -- & -- & -- & -- & -- & -- & $\mathrm{X}$ & -- \\
\hline $\begin{array}{l}\text { Spalding and others, } 2001 \text { (Ne- } \\
\text { braska; nitrate) }\end{array}$ & $\mathrm{X}$ & -- & -- & -- & $\mathrm{X}$ & $\mathrm{X}$ & -- & -- & -- \\
\hline $\begin{array}{l}\text { Spalding and others, } 2003 \text { (Ne- } \\
\text { braska; pesticides) }\end{array}$ & $\mathrm{X}$ & -- & -- & -- & $\mathrm{X}$ & $\mathrm{X}$ & $\mathrm{X}$ & -- & -- \\
\hline $\begin{array}{l}\text { Townsend and others, } 1996 \text { (Kan- } \\
\text { sas; nitrate) }\end{array}$ & -- & -- & -- & -- & $\mathrm{X}$ & $\mathrm{X}$ & -- & $\mathrm{X}$ & -- \\
\hline
\end{tabular}

specific factors (depth to water, well construction, age of well) and to broader geographic factors (irrigation intensity, land use, soil properties). However, statistical correlations between nitrate and explanatory variables commonly were poor due to the large variability in environments across large geographic areas and due to a mixed population of wells affected by point and nonpoint sources of contamination. A study restricted to nonpoint-source contamination in the High Plains aquifer in Nebraska (Druliner and others, 1996) found significant relations between nitrate concentrations and age of well (likely indicative of longer histories of chemical application), irrigation intensity, and soil permeability. A study restricted to nonpoint-source contamination in the High Plains aquifer in Kansas (Helgesen and others, 1994) found land use to be a statistically significant variable relative to nitrate concentrations. Recent regional studies (Center for Disease Control and Prevention, 1998; Nolan and others, 1997; Rupert, 2002) have confirmed that ground water in the High Plains area is susceptible to nitrate contamination. Local-scale studies have examined the relation between nitrate concentrations in ground water and factors like irrigation technique, unsaturated-zone lithology, denitrification, and nitrogen application rate (Fryar and others, 2000; Townsend and others, 1996; Spalding and others, 2001; Böhlke and others, 2007).

Recently, perchlorate has become a chemical of concern in ground water from the High Plains aquifer. Perchlorate interferes with iodide uptake into the thyroid gland. Because iodide is an essential component of thyroid hormones, perchlorate disrupts how the thyroid functions. In adults, the thyroid helps to regulate metabolism. In children, the thyroid plays a major role in proper development in addition to metabolism (U.S. Environmental Protection Agency, 2005). Perchlorate, possibly from natural sources, has been detected in ground water from the southern High Plains aquifer (Jackson and others, 2005; Rajagopalan and others, 2006) and the northern High Plains aquifer (Steven Kalkhoff, U.S. Geological Survey, written commun., 2005). Currently (2007), there is no national regulatory standard for perchlorate in drinking water.

Surveys of the occurrence of pesticides in ground water began appearing in about 1990 for Kansas (Steichen and 


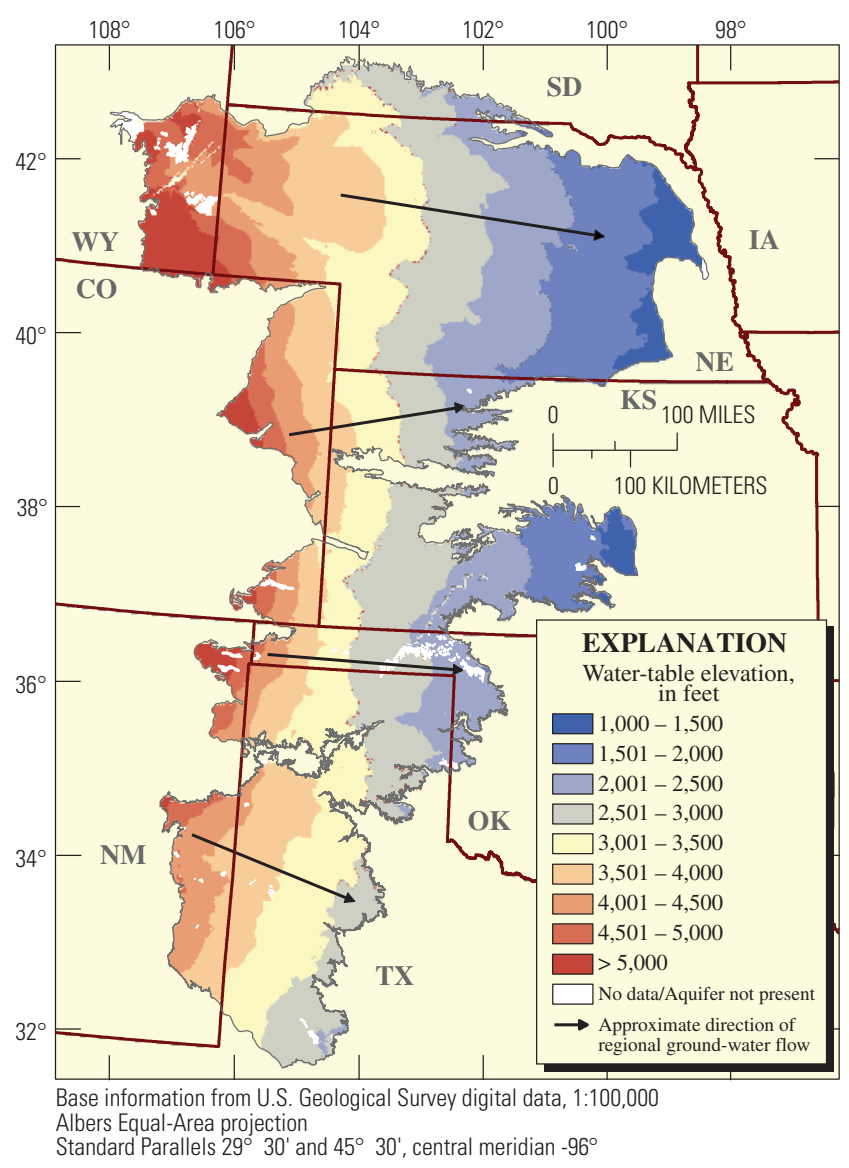

Figure 13. Water-table elevations in the High Plains aquifer, 2000 (V.L. McGuire, U.S. Geological Survey, written commun., 2002).

others, 1988), Texas (Aurelius, 1989), and Nebraska (Exner and Spalding, 1990). Pesticide studies historically have been constrained by analytical considerations (high cost of analysis, large reporting limits, and lack of analytical techniques for pesticides of interest). Those early studies generally reported pesticide detections in only a small proportion of sampled wells, with large concentrations of pesticides occurring rarely; but the documentation of pesticide occurrence in ground water was important because it showed that synthetic chemicals did migrate into the aquifer. Pesticide properties such as water solubility, degradation half-life, and soil sorption index were recognized to cause the mobility of pesticides in the environment to differ from nitrate and from each other. Atrazine, one of the most heavily used pesticides, has chemical properties favorable for mobility in the environment; as a result, atrazine has documented detection frequencies as large as 13 percent of wells sampled (Exner and Spalding, 1990). Detection frequencies in Kansas and Nebraska were found to be highly variable, however, depending on regional environmental conditions. Given the complexity of pesticide mobility in the environment, many recent studies have focused on farm-field scale examinations of pesticide movement (see, for example, Sophocleous and others, 1990; Spalding and others, 2003).

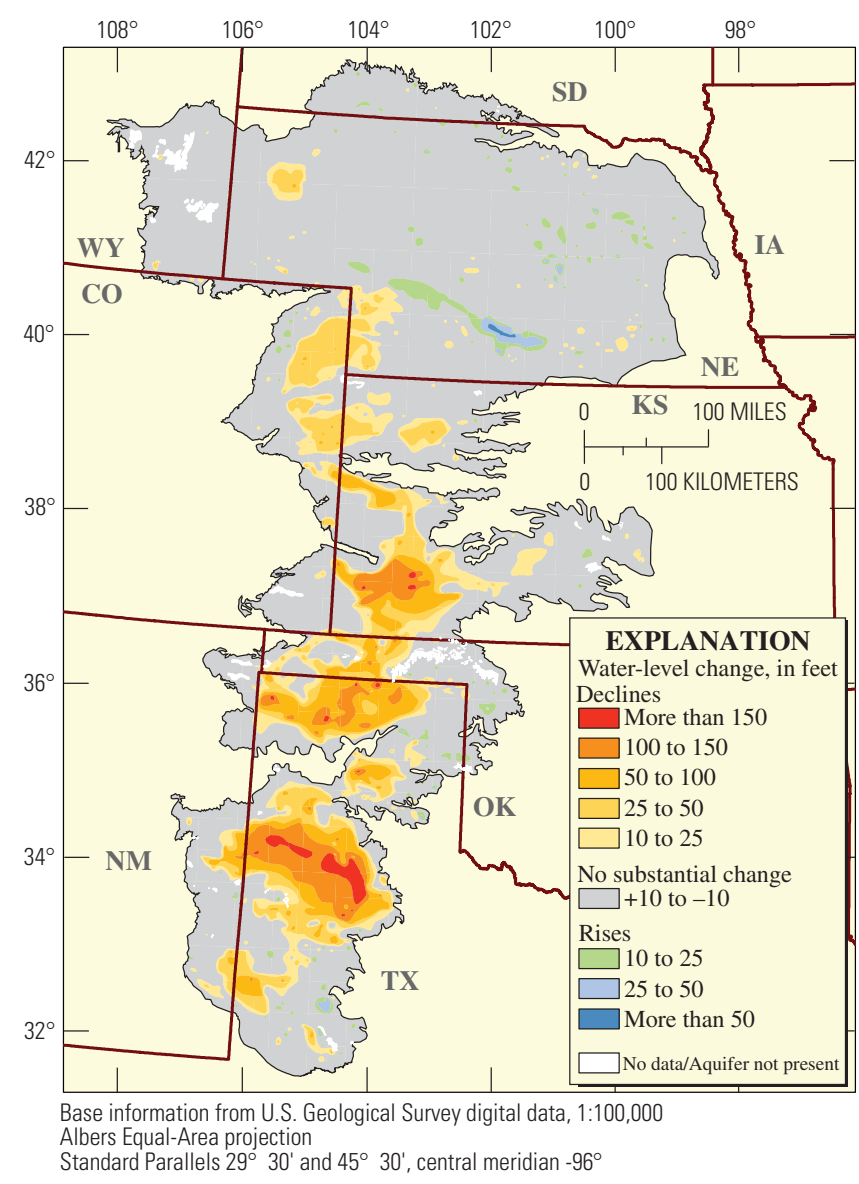

Figure 14. Water-level changes in the High Plains aquifer, predevelopment to 2005. Modified from McGuire (2007).

The previous studies provided valuable information for project planning purposes and later interpretation of HPGW data; however, the existing data were not considered to be suitable for a systematic regional study of water quality across the entire aquifer. Some of the principal limitations of the previous work with respect to a regional water-quality assessment included the following:

1. Inconsistent spatial distribution of well networks used for sample collection in each subregion or State.

2. Different types of wells (irrigation, domestic, public supply, stock, monitoring) used for sample collection in each subregion or State.

3. Inconsistent methods of sample collection.

4. Inconsistent methods of sample analysis. This included inconsistencies with how compounds were analyzed and their associated laboratory reporting levels.

5. Limited set of analytes. 
6. Inconsistent quality-assurance and quality-control plans for field and laboratory analyses.

An important consequence of those limitations is reduced confidence in understanding differences in water quality between subregions and the natural and anthropogenic factors controlling those differences. The HPGW study, described in the following section of the report, did not have those limitations, resulting in a more holistic regional water-quality assessment than could be achieved by using existing data.

\section{Water-Quality Assessment of the High Plains Aquifer}

The review of previous studies indicated that water quality in the High Plains aquifer could be affected by regional differences in geology (fig. 10), climate (figs. 2 and 3), and land use/land cover (fig. 5), among other factors. In addition, limited data on ground-water ages that were available prior to this study indicated that the aquifer could contain water that was recharged from less than 10 years to several thousand years ago (Dutton, 1995). Thus, a monitoring design was needed that could account for this spatial and temporal variability in controlling factors and at the same time address the NAWQA goals of water-quality assessment and process understanding. A stratified, nested group of studies was designed to assess linkages between the quality of water recharging the aquifer, the effect of transport through the hydrologic system on water quality, and the quality of the resource used for human consumption and irrigation. These STR study components were designed to address the NAWQA goals of water-quality assessment (status or baseline) and process understanding. The process component included the study of critical processes or factors of regional importance such as recharge, groundwater flow directions and ages, and gradients in land use/ land cover and climate that helped to explain baseline conditions. The stratified, nested design facilitated up-scaling of monitoring (assessment) results to unmonitored areas of the aquifer as well as up-scaling of process understanding from local to regional scales. Additionally, the stratified, nested design facilitated down-scaling of regional information such as climate and land-use/land-cover gradients to help explain local processes. The following paragraphs describe the stratification scheme, the nested study components, and their relation to the NAWQA goals.

The aquifer was stratified on the basis of climate, hydrogeology, and land use/land cover for subsequent water-quality monitoring. The Level 1 stratification, based on climate, produced three major subregions: the NHP, CHP, and the SHP (table 3 and fig. 15). Each of those major subregions was then stratified on the basis of hydrogeology to produce a total of nine Level 2 subareas: the alluvial systems in the NHP and CHP; Quaternary deposits in the CHP; Sand Hills eolian deposits in the NHP; Plio-Pleistocene deposits in the NHP; Ogallala Formation in the NHP, CHP, and SHP; and the Arika-
ree-Brule Formations in the NHP (table 3 and fig. 10A). The Level 3 stratification further subdivided selected areas with similar hydrogeologic characteristics into areas with similar land use/land cover, either irrigated cropland, rangeland, or urban (table 3 and fig. 15). Within a given Level 3 subarea, climate, hydrogeology, and land use/land cover are expected to be relatively uniform from the regional perspective; thus, data from sampled wells in the subarea presumably can be extrapolated to unmonitored parts of the subarea (spatial up-scaling).

The HPGW study consisted primarily of four components: unsaturated-zone studies, land-use studies, regional transect studies, and major-aquifer studies. Characteristics of those study components are summarized in table 4 . The purpose of the unsaturated-zone studies was to measure chemical storage and transit times in the unsaturated zone beneath rangeland and irrigated cropland in the Ogallala Formation. Rangeland and cropland are primary land uses/land covers in the High Plains (fig. 5), and the Ogallala Formation is the largest hydrogeologic unit of the aquifer (fig. 10A). Results of those studies are summarized in Chapter 1 ("Sources" chapter). Details of the unsaturated-zone studies are described by McMahon and others $(2003,2006)$. The purpose of the land-use studies was to assess the quality of recently recharged ground water (less than 50 years old) beneath major land-use/ land-cover settings by sampling networks of randomly distributed monitoring wells screened near the water table beneath those targeted land uses/land covers. Land-use studies were conducted in four Level 2 subareas, and they targeted irrigated agriculture and urban areas (table 4). Results of the agricultural land-use studies are summarized in Chapter 1 ("Sources" chapter). Details of the land-use studies are described by Pope and others (2002) (urban study), Bruce and others (2003), and Stanton and Fahlquist (2006). The purposes of the regional transect studies were to characterize vertical gradients in water chemistry and age in selected Level 2 subareas and to identify major biogeochemical reactions affecting the quality of water along flow paths from recharge areas to downgradient wells. Results of those studies are summarized in Chapter 2 ("Transport" chapter). Details of the regional transect studies are described by McMahon (2001) and McMahon and others (2004a, b; 2007). The purpose of the major-aquifer studies was to broadly assess water-quality conditions in the aquifer by sampling networks of randomly distributed, existing domestic wells in the major hydrogeologic units (Level 2 subareas). Major-aquifer studies were conducted in six of the nine Level 2 subareas, accounting for 83 percent of the aquifer area. A major-aquifer study was previously conducted by NAWQA in the Platte River alluvial system in the NHP (Stanton and Qi, 2007). Results of the major-aquifer studies are summarized in Chapter 3 ("Receptors" chapter). Details of the major-aquifer studies are described by Pope and others (2001), Becker and others (2002), Fahlquist (2003), and Stanton and Qi (2007).

A key component of the HPGW design was nesting of the studies described in table 4, which resulted in improved understanding of assessment results and supported their extrapolation to unmonitored areas of the aquifer. An example of the 
Table 3. Stratification scheme used in the High Plains Regional Ground-Water Study. [--, not applicable]

\begin{tabular}{|c|c|c|}
\hline $\begin{array}{c}\text { Climate } \\
\text { (Level } 1 \text { stratification) }\end{array}$ & $\begin{array}{c}\text { Hydrogeology } \\
\text { (Level } 2 \text { stratification) }\end{array}$ & $\begin{array}{l}\text { Land use/land cover } \\
\text { (Level } 3 \text { stratification) }\end{array}$ \\
\hline \multirow{7}{*}{ Northern High Plains } & Alluvial systems & -- \\
\hline & Sand Hills eolian deposits & -- \\
\hline & \multirow{2}{*}{ Plio-Pleistocene deposits } & Irrigated corn/soybeans \\
\hline & & Urban \\
\hline & \multirow{2}{*}{ Ogallala Formation } & Rangeland \\
\hline & & Irrigated corn \\
\hline & Arikaree-Brule Formations & -- \\
\hline \multirow{4}{*}{ Central High Plains } & Alluvial systems & -- \\
\hline & Quaternary deposits & Urban \\
\hline & \multirow{2}{*}{ Ogallala Formation } & Rangeland \\
\hline & & Irrigated corn \\
\hline \multirow{2}{*}{ Southern High Plains } & \multirow{2}{*}{ Ogallala Formation } & Rangeland \\
\hline & & Irrigated cotton \\
\hline
\end{tabular}

nested design implemented in the CHP is shown in figure 16. Nested within the major-aquifer study for the CHP Ogallala Formation was a land-use study targeting irrigated corn, and nested within the land-use study was an unsaturated-zone study of agricultural-chemical storage and transit time in the unsaturated zone. Also nested within the major-aquifer study was a regional transect study characterizing vertical gradients in water chemistry and age between the water table and base of aquifer. By monitoring water and chemical movement from the land surface to the water table and from the water table to the base of the aquifer along flow paths leading from recharge to discharge areas, the nested design not only facilitated extrapolation of assessment results, it also improved understanding of the timescales at which that movement occurred. The spatially and temporally integrated design for assessing water quality in regional aquifer systems, illustrated schematically in fig. 17, has the advantage of enabling interpretation of local-scale data over a broad range of variability contained within the resource. Thus, a beneficial aspect of the High Plains study design is that it bridges the interpretation gap between local-scale studies and the aggregation to a regionalscale synthesis.

The following four chapters summarize results of the HPGW study. Chapter 1 discusses the chemical quality of recent recharge in the aquifer and the natural and human factors affecting that quality (Source). Chapter 2 discusses ground-water residence times and chemical reactions along flow paths from recharge areas to downgradient wells in the aquifer (Transport). Chapter 3 uses the source and transport information as the basis for assessing the quality of water pumped from domestic, irrigation, and public-supply wells in the aquifer (Receptor). Finally, Chapter 4 discusses implications of the water-quality findings with respect to water availability and sustainability of the High Plains aquifer. 
Table 4. Primary components of the High Plains Regional Ground-Water study.

[NHP; northern High Plains; CHP, central High Plains; SHP, southern High Plains]

\begin{tabular}{|c|c|c|c|c|c|c|}
\hline $\begin{array}{c}\text { Study } \\
\text { component }\end{array}$ & Well type & $\begin{array}{l}\text { Network } \\
\text { purpose }\end{array}$ & $\begin{array}{l}\text { Water-quality } \\
\text { properties and } \\
\text { constituents }\end{array}$ & $\begin{array}{l}\text { Sampling } \\
\text { frequency }\end{array}$ & Network locations & $\begin{array}{c}\text { Number of } \\
\text { wells }\end{array}$ \\
\hline $\begin{array}{l}\text { Unsaturated- } \\
\text { zone studies }\end{array}$ & $\begin{array}{l}\text { Monitoring } \\
\text { wells with } \\
10 \text {-foot-long } \\
\text { screens placed } \\
\text { near water } \\
\text { table. Various } \\
\text { instruments in } \\
\text { the unsaturated } \\
\text { zone to measure } \\
\text { water content } \\
\text { and water and } \\
\text { gas chemistry }\end{array}$ & $\begin{array}{l}\text { Measure } \\
\text { chemical stor- } \\
\text { age and transit } \\
\text { times in the } \\
\text { unsaturated } \\
\text { zone in Level } \\
3 \text { strata (see } \\
\text { table } 3 \text { and } \\
\text { Chapter } 1 \text { ). } \\
\text { [PROCESS] }\end{array}$ & $\begin{array}{l}\text { Ground Water: } \\
\text {-Physical proper- } \\
\text { ties, dissolved } \\
\text { oxygen } \\
\text {-Major ions, } \\
\text { nutrients, trace } \\
\text { elements } \\
\text {-Multiple stable } \\
\text { isotopes and dis- } \\
\text { solved gases, } \\
\text { tritium } \\
\text {-Dissolved organic } \\
\text { carbon, pesticide } \\
\text { compounds } \\
\text { Unsaturated zone: } \\
\text {-Chloride, nitrate, } \\
\text { tritium, Multiple } \\
\text { stable isotopes and } \\
\text { gases } \\
\text {-Pesticide com- } \\
\text { pounds }\end{array}$ & $\begin{array}{l}\text { Multiple } \\
\text { times }\end{array}$ & $\begin{array}{l}\text { CHP, Ogallala Forma- } \\
\text { tion, irrigated corn and } \\
\text { rangeland } \\
\text { SHP, Ogallala Forma- } \\
\text { tion, irrigated cotton and } \\
\text { rangeland }\end{array}$ & 2 \\
\hline Land-use studies & $\begin{array}{l}\text { Monitoring } \\
\text { wells with } \\
\text { 10-foot-long } \\
\text { screens } \\
\text { placed near } \\
\text { water table }\end{array}$ & $\begin{array}{l}\text { Characterize } \\
\text { the quality } \\
\text { of recently } \\
\text { recharged } \\
\text { water in Level } \\
3 \text { strata (see } \\
\text { table } 3 \text { and } \\
\text { Chapter } 1 \text { ). } \\
\text { [ASSESS- } \\
\text { MENT/PRO- } \\
\text { CESS] }\end{array}$ & $\begin{array}{l}\text {-Physical proper- } \\
\text { ties, dissolved } \\
\text { oxygen } \\
\text {-Major ions, } \\
\text { nutrients, trace } \\
\text { elements } \\
\text {-Stable isotopes of } \\
\text { nitrate } \\
\text {-Tritium } \\
\text {-Dissolved organic } \\
\text { carbon } \\
\text {-Pesticide com- } \\
\text { pounds } \\
\text {-Volatile organic } \\
\text { compounds (urban } \\
\text { land use only) }\end{array}$ & 1 time & $\begin{array}{l}\text { NHP, Plio-Pleistocene } \\
\text { deposits, irrigated corn/ } \\
\text { soybeans } \\
\text { CHP, Ogallala Forma- } \\
\text { tion, irrigated corn }\end{array}$ & 30 \\
\hline $\begin{array}{l}\text { Regional transect } \\
\text { studies }\end{array}$ & $\begin{array}{l}\text { Monitoring } \\
\text { wells with } \\
\text { 10-foot-long } \\
\text { screens } \\
\text { nested } \\
\text { between the } \\
\text { water table } \\
\text { and base of } \\
\text { aquifer }\end{array}$ & $\begin{array}{l}\text { Characterize } \\
\text { vertical gradi- } \\
\text { ents in water } \\
\text { chemistry and } \\
\text { age in Level } 2 \\
\text { strata. Identify } \\
\text { major biogeo- } \\
\text { chemical reac- } \\
\text { tions affecting } \\
\text { water quality } \\
\text { along flow } \\
\text { paths from } \\
\text { recharge areas } \\
\text { to downgradi- } \\
\text { ent wells (see } \\
\text { table } 3 \text { and } \\
\text { Chapter 2). } \\
\text { [PROCESS] }\end{array}$ & $\begin{array}{l}\text {-Physical proper- } \\
\text { ties, dissolved } \\
\text { oxygen } \\
\text {-Major ions, nutri- } \\
\text { ents, trace elements } \\
\text {-Multiple stable } \\
\text { isotopes and dis- } \\
\text { solved gases } \\
\text {-Tritium, carbon } \\
\text { 14, radon } \\
\text {-Dissolved organic } \\
\text { carbon, pesticide } \\
\text { compounds }\end{array}$ & 1 time & 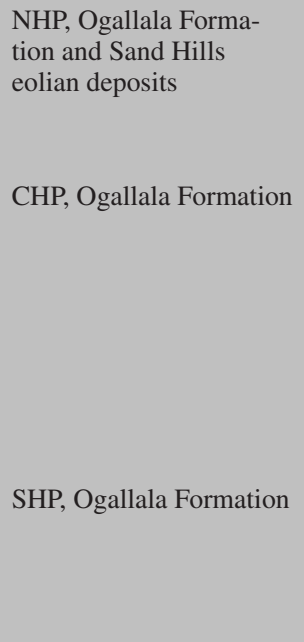 & 19 \\
\hline
\end{tabular}


Table 4. Primary components of the High Plains Regional Ground-Water study.-Continued

[NHP; northern High Plains; CHP, central High Plains; SHP, southern High Plains]

\begin{tabular}{|c|c|c|c|c|c|c|}
\hline $\begin{array}{c}\text { Study } \\
\text { component }\end{array}$ & Well type & $\begin{array}{c}\text { Network } \\
\text { purpose }\end{array}$ & $\begin{array}{c}\text { Water-quality } \\
\text { properties and } \\
\text { constituents }\end{array}$ & $\begin{array}{l}\text { Sampling } \\
\text { frequency }\end{array}$ & Network locations & $\begin{array}{c}\text { Number of } \\
\text { wells }\end{array}$ \\
\hline $\begin{array}{l}\text { Major-aquifer } \\
\text { studies }\end{array}$ & $\begin{array}{l}\text { Domestic } \\
\text { wells }\end{array}$ & $\begin{array}{l}\begin{array}{l}\text { Broadly } \\
\text { characterize } \\
\text { water quality }\end{array} \\
\text { in Level } 2 \\
\text { strata (see } \\
\text { table } 3 \text { and } \\
\text { Chapter 3). } \\
\text { [ASSESS- } \\
\text { MENT] }\end{array}$ & $\begin{array}{l}\text {-Physical proper- } \\
\text { ties, dissolved } \\
\text { oxygen } \\
\text {-Major ions, nutri- } \\
\text { ents, trace elements } \\
\text {-Radon } \\
\text {-Tritium (selected } \\
\text { wells) } \\
\text {-Dissolved organic } \\
\text { carbon } \\
\text {-Pesticide com- } \\
\text { pounds } \\
\text {-Volatile organic } \\
\text { compounds }\end{array}$ & 1 time & $\begin{array}{l}\text { NHP, Sand Hills eolian } \\
\text { deposits } \\
\text { NHP, Plio-Pleistocene } \\
\text { deposits } \\
\text { NHP, Ogallala Forma- } \\
\text { tion } \\
\text { CHP, Quaternary } \\
\text { deposits } \\
\text { CHP, Ogallala Formation } \\
\text { SHP, Ogallala Formation }\end{array}$ & $\begin{array}{l}114 \\
20 \\
67\end{array}$ \\
\hline
\end{tabular}


Climate

(Level 1 stratification)

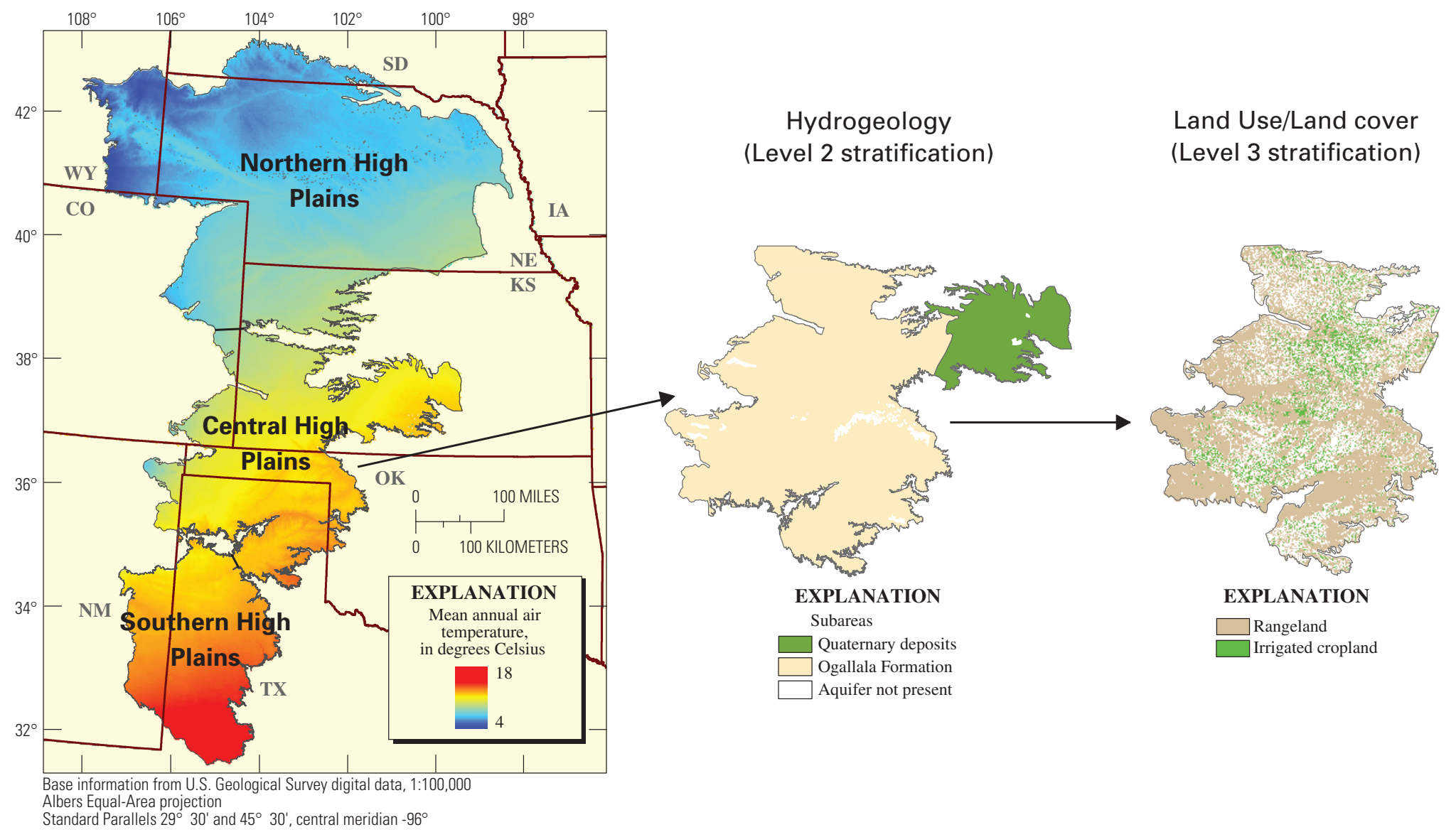

Figure 15. Example of the stratification process used for the central High Plains subregion in the High Plains Regional Ground-Water study. 


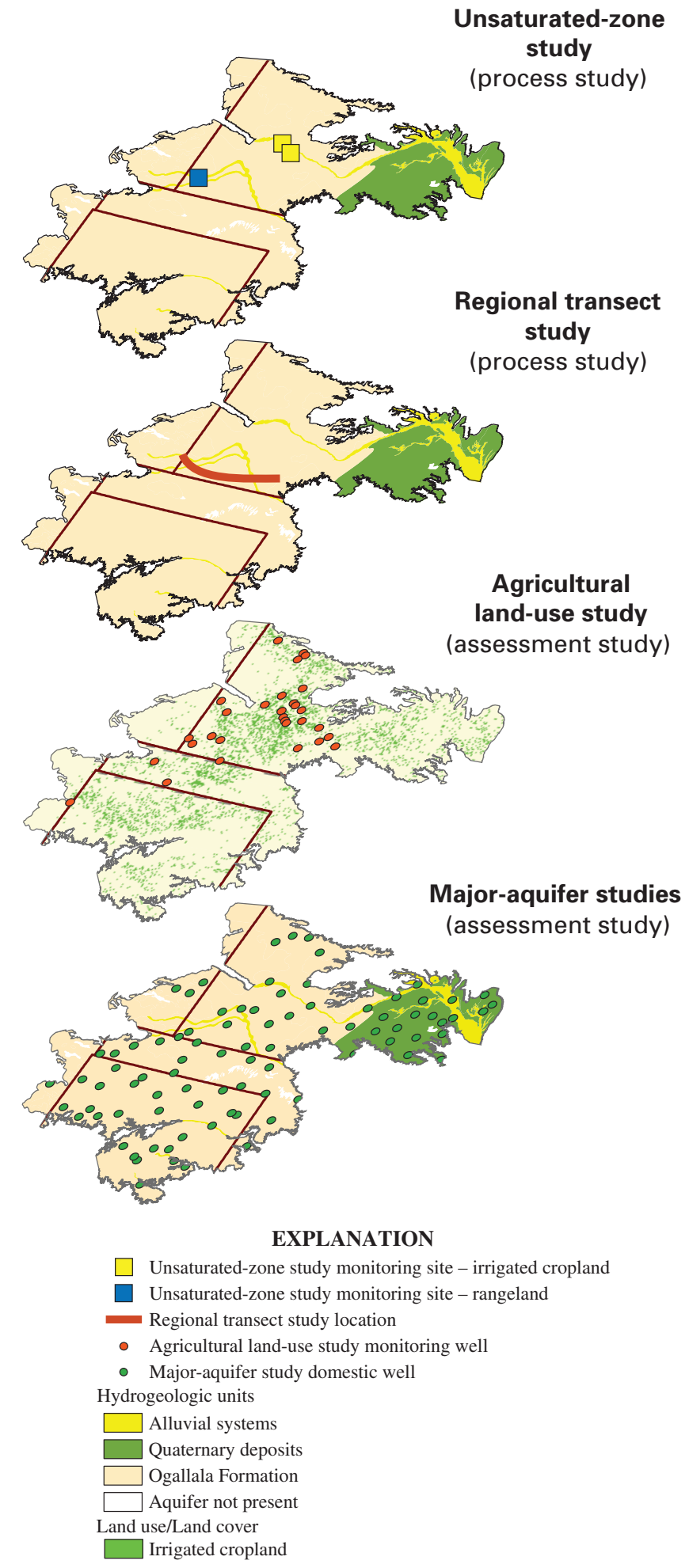

Figure 16. Nested design used in the central High Plains subregion. 


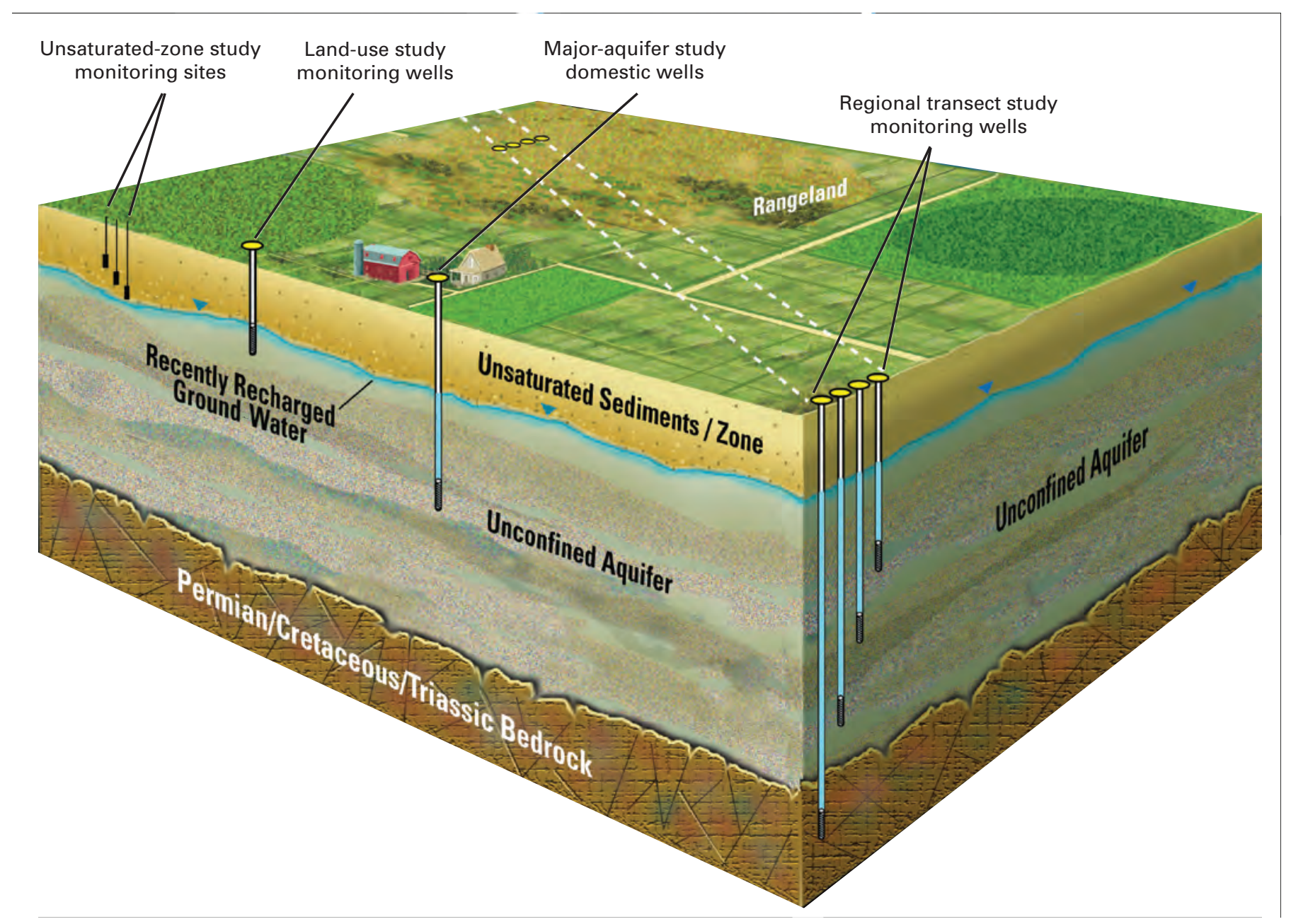

Figure 17. Schematic representation of the holistic monitoring design used in the High Plains Regional Ground-Water study. 